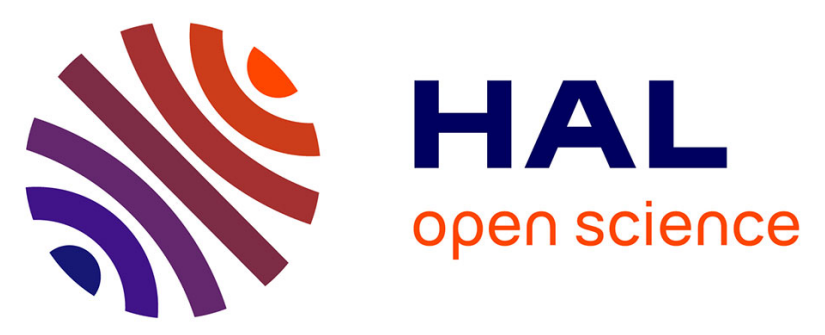

\title{
Integrated geophysical, sedimentological and geotechnical investigation of submarine landslides in the Gulf of Lions (Western Mediterranean)
}

\author{
Shray Badhani, Antonio Cattaneo, Stefano Collico, Roger Urgeles, Bernard
} Dennielou, Estelle Leroux, Florent Colin, Sebastien Garziglia, Marina

Rabineau, Laurence Droz

\section{To cite this version:}

Shray Badhani, Antonio Cattaneo, Stefano Collico, Roger Urgeles, Bernard Dennielou, et al.. Integrated geophysical, sedimentological and geotechnical investigation of submarine landslides in the Gulf of Lions (Western Mediterranean). Subaqueous Mass Movements and their Consequences: Advances in Process Understanding, Monitoring and Hazard Assessments, 500, pp.359 - 376, 2020, 10.1144/sp5002019-175 . hal-03099506

\section{HAL Id: hal-03099506 https://hal.science/hal-03099506}

Submitted on 6 Jan 2021

HAL is a multi-disciplinary open access archive for the deposit and dissemination of scientific research documents, whether they are published or not. The documents may come from teaching and research institutions in France or abroad, or from public or private research centers.
L'archive ouverte pluridisciplinaire HAL, est destinée au dépôt et à la diffusion de documents scientifiques de niveau recherche, publiés ou non, émanant des établissements d'enseignement et de recherche français ou étrangers, des laboratoires publics ou privés. 
Accepted Manuscript

\title{
Geological Society, London, Special Publications
}

\section{Integrated geophysical, sedimentological and geotechnical investigation of submarine landslides in the Gulf of Lions (Western Mediterranean)}

\author{
Shray Badhani, Antonio Cattaneo, Stefano Collico, Roger Urgeles, Bernard \\ Dennielou, Estelle Leroux, Florent Colin, Sebastien Garziglia, Marina Rabineau \\ \& Laurence Droz
}

DOI: https://doi.org/10.1144/SP500-2019-175

Received 30 September 2019

Revised 29 November 2019

Accepted 29 November 2019

(C) 2020 The Author(s). Published by The Geological Society of London. All rights reserved. For permissions: http://www.geolsoc.org.uk/permissions. Publishing disclaimer:

www.geolsoc.org.uk/pub_ethics

Supplementary material at http://igsn.org/BFBGX-87813

Supplementary material at http://igsn.org/BFBGX-87814

Supplementary material at http://igsn.org/BFBGX-87815

To cite this article, please follow the guidance at

https://www.geolsoc.org.uk/ /media/Files/GSL/shared/pdfs/Publications/AuthorInfo_Text.pdf?la=en

\section{Manuscript version: Accepted Manuscript}

This is a PDF of an unedited manuscript that has been accepted for publication. The manuscript will undergo copyediting, typesetting and correction before it is published in its final form. Please note that during the production process errors may be discovered which could affect the content, and all legal disclaimers that apply to the book series pertain.

Although reasonable efforts have been made to obtain all necessary permissions from third parties to include their copyrighted content within this article, their full citation and copyright line may not be present in this Accepted Manuscript version. Before using any content from this article, please refer to the Version of Record once published for full citation and copyright details, as permissions may be required. 


\title{
Integrated geophysical, sedimentological and geotechnical investigation of submarine landslides in the Gulf of Lions (Western Mediterranean)
}

Shray Badhani ${ }^{1,2}$, Antonio Cattaneo ${ }^{1}$, Stefano Collico ${ }^{3}$, Roger Urgeles ${ }^{4}$, Bernard Dennielou ${ }^{1}$, Estelle Leroux ${ }^{1}$, Florent Colin ${ }^{1,2}$, Sebastien Garziglia ${ }^{1}$, Marina Rabineau ${ }^{2}$, Laurence Droz ${ }^{2}$

${ }^{1}$ : IFREMER, Unité de Recherche Géosciences Marines, Centre de Bretagne, 1625 Route de Sainte-Anne, 29280 Plouzané, France.

2: Univ. Brest, CNRS, Univ. Bretagne-Sud, Laboratoire Géosciences Océan,UMR6538 IUEM, rue Dumont d'Urville, F-29280 Plouzané, France.

3: Igeotest, Carrer Holanda, Num 14 - Poligon Recinte Firal, 17600 Figueres, Girona, Spain

4: Institut de Ciències del Mar (CSIC), Pg.Marítim de la Barceloneta, 37-49, 08003

Barcelona, Spain.

Corresponding author: Shray Badhani (shray.badhani@ifremer.fr)

\begin{abstract}
The Gulf of Lions presents recurring mass-transport deposits (MTDs) within the PlioQuaternary sediments suggesting a long history of mass movements. The two large, surficial MTDs are located on the eastern and western levee of the Rhone canyon over an area exceeding $6000 \mathrm{~km}^{2}$ and volumes exceeding $100 \mathrm{~km}^{3}$. Both MTDs were emplaced $21 \mathrm{ka}$ ago (peak of the Last Glacial Maximum), suggesting a common trigger. Here, we present a multidisciplinary high-resolution geophysical, sedimentological and in-situ geotechnical study of the source and deposit areas of both MTDs to characterise distinct expressions of sediment deformation as well as their spatial and chronological distributions. We show the internal structure of mass movements and resulting MTDs with unprecedented details that were previously represented in the conventional seismic data as transparent and chaotic facies. The combination of multidisciplinary approaches shows new insights into the nature of basal surfaces of the slope failures. In particular, we show that the basal surfaces of the failures consist of clay-rich material contrasting with the overlying turbiditic deposits, suggesting that a strong lithological heterogeneity exists within the strata. We suggest that
\end{abstract}


this change in lithology between clay-rich sediments and turbiditic sequences most likely control the localisation of weak layers and landslide basal surfaces.

Supplementary material: Sediment cores are curated at IFREMER core repository in Plouzané (France); core data related to this article are available at: http://igsn.org/BFBGX87813 (core PSM3-CS049: IGSN BFBGX-87813); http://igsn.org/BFBGX-87814 (core PSM3-CS050: IGSN BFBGX-87814); http://igsn.org/BFBGX-87815 (core PSM3-CS051: IGSN BFBGX-87815) 
Submarine landslides have been widely recognised on passive and active continental margins, in a wide range of environments, including submarine canyons (Sultan et al. 2007a; Micallef et al. 2012), carbonate platforms (Principaud et al. 2014), siliciclastic platforms (Silva et al. 2010) and volcanic islands (Moore et al. 1989; Urgeles et al. 1997; Le Friant et al. 2015). These landforms have a profound effect on shaping margin's architecture (Posamentier \& Kolla 2003), providing useful insights into the evolution of continental margins, along with providing constraints on palaeoseismicity (St-Onge et al. 2004; Brooks 2016; Moernaut et al. 2017; Praet et al. 2017). Submarine landslides are regarded as important marine geological processes given their widespread occurrences and potentially large volumes $\left(>10^{3} \mathrm{~km}^{3}\right.$; Hampton et al. 1996; Masson et al. 2006; Talling et al. 2014), that is able to redistribute significant amount of sediments from the shelf or the upper slopes of the margins to the lower slopes or the surrounding deep basin. Moreover, submarine landslides can be two to three orders of magnitude larger, in terms of volume, than their terrestrial counterparts (Hampton et al. 1996; Masson et al. 2006), and therefore threaten offshore infrastructure. Submarine landslides also hold a high hazard potential for tsunamigenic risks, which can be devastating to increasingly populated coastlines (Tappin et al. 1999; Bryn et al. 2003, 2005; Kvalstad et al. 2005; Heidarzadeh et al. 2018; Carvajal et al. 2019; Sassa \& Takagawa 2019).

Due to their locations in deep-water environments, direct observation of submarine landslides and their deposits is difficult. Therefore, geophysical techniques are used to observe submarine landslides such as multibeam bathymetry, reflection seismic and often sediment cores are collected to ground truth geophysical data. In reflection seismic data, submarine landslide deposits are generally referred to as mass transport deposits (MTDs) and mass transport complexes (Alves 2015). MTDs in the seismic data are often defined by acoustically transparent or chaotic facies (Damuth 1980). However, outcrop examples often show a complex internal geometry including seismic-scale folding and faulting, contorted lithologies and slide blocks within the MTDs that can be used as kinematic indicators (Ogata et al. 2014, 2016).

Often the failure surface (i.e., the basal surface or glide plane) over which the mass movement of sediments occurs develops at the base of a weak layer and follow stratigraphic horizons (Baeten et al. 2014). Landslide basal surfaces are identified on seismic profiles by high-amplitude reflections (Baeten et al. 2014). In order to understand mass wasting processes and to correctly perform geohazard assessments, identification and analysis of weak layers and basal surfaces is imperative (Lastras et al. 2004; Kvalstad et al. 2005; 
L'Heureux et al. 2012). Due to alteration in physical properties during failure or due to the occurrence of thick post-failure sedimentary sequences, weak layers and basal surfaces are rarely penetrated using current coring techniques. Therefore, only a few studies have reported information about failure-related weak layers and basal surfaces of submarine landslides (e.g. Kvalstad et al. 2005; Dan et al. 2007; L’Heureux et al. 2012; Baeten et al. 2014; Miramontes et al. 2018; Urlaub et al. 2018)

Submarine landslides in the Gulf of Lions (GoL) are widespread from the upper slope to the deep basin, within the canyon flanks and in the interfluves of major canyons (Fig. 1). The two main submarine landslides present in the GoL are the Eastern Rhône Interfluve Slide (ERIS, Badhani et al. 2019) and an unnamed slide complex on the western side of the Petit Rhone Canyon (PRC, Dennielou et al. 2019) that we refer to as the Western Slide in this paper. Their resulting MTDs, the Rhone Eastern MTD (REMTD) and the Rhone Western MTD (RWMTD) have previously been described in detail in many studies (Droz \& Bellaiche 1985; Torres et al. 1997; Droz et al. 2001, 2006; Bonnel et al. 2005; Dennielou et al. 2019). However, due to the lack of high-resolution multidisciplinary dataset, such as high-resolution seismic, sediment cores, in-situ geotechnical measurements, a detailed analysis of weak layers and preconditioning factors was never performed. The overarching aim of this study is to analyse for the first time a suite of multidisciplinary dataset to better understand the distribution and characters of seafloor instabilities in the GoL. Specifically, the objectives of this paper are: 1) using deep-towed multichannel seismic data to image the internal structure of the mass-wasting products, previously imaged as seismically transparent or chaotic intervals in conventional seismic data; 2) use very high-resolution seismic, sedimentological data and in-situ geotechnical measurements to analyse the basal surfaces of the slope failures in the GoL.

\section{Geological Setting}

The GoL (Fig. 1) is a SW-NE orientated passive margin that is described by a wide continental shelf of $\sim 70 \mathrm{~km}$, which was sub-aerially exposed during the Last Glacial Maximum (LGM) about 21 ka ago (Rabineau et al. 2005; Berné et al. 2007; Jouet 2007; Bassetti et al. 2008). Sedimentary succession composing the distal Rhone Sedimentary System originates from fifteen distinct submarine canyons. The major canyon feeding the Rhone Sedimentary System is the PRC, located in the central part of the study area (Fig. 1), which is fed by Alpine sediments through the Rhone River and its tributaries. 
During the Messinian Salinity Crisis ( 5.33 Ma ago, Lofi et al. 2003; Roveri et al. 2008), a major drop in the Mediterranean sea level led to a basin-wide accumulation of a km-scale thick evaporite succession (Hsu 1973). This changed the sedimentary architecture of the GoL drastically. Since then, syn-sedimentary salt tectonics and gravity-driven deformation of Pliocene and Quaternary strata mainly control the evolution of the deeper part of the GoL (dos Reis et al. 2005). As a result of the gravity-driven deformation above the salt layer, which acts as a "décollement" surface, several extensional areas developed, where listric faults and grabens predominate in the upper and lower slopes (Fig. 1), and formed compressional areas in the deep basin driven by salt diapirs and domes (dos Reis et al. 2005). Subsequent glacio-eustatic sea level fluctuations related to the Milankovitch cyclicities mostly control the Pleistocene sedimentation in the GoL (Rabineau et al. 1998, 2005; Tesson \& Gensous 1998; Bassetti et al. 2008). After the Mid-Pleistocene, sedimentation within the GoL mainly consisted of terrigenous sediments from the Alpine rivers (mainly Rhone River) delivered to the basin through turbiditic systems. The lower slope of the GoL (1500-2000 m water depth) is mainly fed by the PRC (Lombo Tombo et al. 2015). Sedimentation rates in the lower slopes during the glacial and deglacial periods were reported to be of the order of 1$3 \mathrm{~m} / \mathrm{ka}$ (Sierro et al. 2009; Dennielou et al. 2019). During the interglacial periods, the sedimentation rates were much lower falling in the range of 0.05 to $0.10 \mathrm{~m} / \mathrm{ka}$ (Sierro et al. 2009; Lombo Tombo et al. 2015; Dennielou et al. 2019).

Within the GoL, immediately at the foot of the slope, two large submarine landslides, the ERIS and the Western Slide have been recognized and investigated by Bellaiche et al. (1986), Droz et al. (2006), Dennielou et al. (2019) and Badhani et al. (2019). The ERIS extends from the shelf break ( $120 \mathrm{~m}$ ) to the water depths $1500 \mathrm{~m}$ on the eastern side of the PRC (Badhani et al. 2019), and Western Slide complex extends from $1800 \mathrm{~m}$ to $2300 \mathrm{~m}$ on the western side of the PRC (Dennielou et al. 2019). The ERIS consists of successive headwall scarps of 30$120 \mathrm{~m}$ height aligned in a staircase style and the Western landslide consists of several scarps parallel to the slope whose heights reach 50-100 m (Fig. 2). The resulting deposits, the REMTD and RWMTD have surface areas exceeding $6500 \mathrm{~km}^{2}$, volumes greater than 100 $\mathrm{km}^{3}$ and an extremely long run out of more than $200 \mathrm{~km}$ (Droz et al. 2006). Both landslides occurred during the peak of the last glacial maximum (21 ka cal BP) suggesting a common trigger behind the failure (Badhani et al. 2019; Dennielou et al. 2019). Badhani et al. (2019) showed repeated slope failures above high-amplitude horizons at different stratigraphic levels, indicating control of specific sediment type on the failure. 


\section{Material and Methods}

\section{Geophysical data}

To characterise the morphology of the study area, we use an openly available European Marine Observation and Data Network (EMODnet) $115 \mathrm{~m}$ resolution multibeam bathymetry (Fig.1; www.emodnet-bathymetry.eu, 2018) and a 25 m resolution high-resolution bathymetry acquired during several French cruises (for details see Dennielou et al. 2019). The 2D high-resolution (HR) multi-channel seismic (MCS) reflection data (Figs. 3-5) used in this study were acquired during two surveys, PRISME2 onboard R/V L'Atalante (Cattaneo 2013a) and AM-MED onboard R/V Le Suroit (Rabineau et al. 2013). The processing sequence for the 2D HR MCS data includes quality control, filtering, binning (6.25 m), bandpass filtering (15-30-375-400 Hz), seawater velocity $\left(1500 \mathrm{~m} \mathrm{~s}^{-1}\right)$ normal move out, stacking, and seawater velocity post-stack Kirchoff time migration.

Two-dimensional deep-towed multichannel very high-resolution seismic data (Fig. 6) were acquired for the first time in the GoL during PRISME2 campaign (Cattaneo, 2013a) using Ifremer's in-house acquisition system SYSIF (SYstème SIsmique de Fond, Ker et al. 2010; Marsset et al. 2014). It consists of an open-cavity acoustic source and a specially developed streamer that is towed at a constant altitude above the seafloor $(50-100 \mathrm{~m})$. The source consists of a Janus-Helmholtz transducer that emits a $100 \mathrm{~ms}$ sweep signal in the 220-1050 $\mathrm{Hz}$ frequency bandwidth. The multichannel streamer is composed of 52 digital hydrophones spaced by $2 \mathrm{~m}$ (offsets $10-112 \mathrm{~m}$ ). The processing of the data includes a reconstruction of the variable streamer geometry, a deconvolution of the seismic signal by the source signature and a Kirchhoff pre-stack depth migration. SYSIF can obtain a maximum vertical resolution of $0.6 \mathrm{~m}$ and up to $1.5 \mathrm{~m}$ horizontally, that allows us to image mass-movement features in unprecedented detail.

\section{Sediment cores}

Lithological characterisation and age estimation of sedimentary facies are based on three sediment cores PSM3-CS049, 50 and 51 collected during cruise PRISME 3 (Cattaneo 2013b) on the GoL slope using a Calypso Piston corer. These cores respectively penetrated $9.20 \mathrm{~m}$, $11.26 \mathrm{~m}$ and $2265 \mathrm{~m}$ deep (Fig. 7), and were corrected for true depth using Ifremer software CINEMA $^{2}$ based on accelerometer measurements performed during coring. Identification of lithofacies is based on the visual description, which was partially performed onboard and 
partially at Ifremer-Brest. Geotek® Multi-Sensor Core Logger (MSCL) was used for gammadensity and p-wave velocity (Vp) measurements at 1-cm intervals (Fig. 7). Bulk X-ray fluorescence (XRF) was measured with the Avaatech XRF core scanner on split cores at 1cm interval (Fig.7). Grain-size analysis was performed on core PSM3-CS050 using a laser diffractometer device at CSIC-ICM, Barcelona in 2019 (Fig. 8a). Vane shear tests on sediment core PSM3-CS050 at $10 \mathrm{~cm}$ interval were performed at Ifremer-Brest (Fig. 8b).

Three radiocarbon dates (Fig. 7) were determined by accelerator mass spectrometry (AMS) on core PSM3-CS049. Dates were obtained from handpicked monospecific planktonic foraminifera (Globigerina bulloides) extracted from the hemipelagic sediments and were analysed at the Beta Analytics, London, UK. Conventional 14C ages were converted into calibrated calendar ages with CALIB V7.1 (Stuiver et al. 2017) using the Marine13 curve for calibration (Reimer et al. 2013) with a reservoir correction $(\Delta \mathrm{R})$ value of $48 \pm 101$ years and reported in this study with with an error of two standard deviations (Tab. 1).

\section{In-situ geotechnical measurements}

Five in-situ geotechnical measurements were carried out using the Penfeld seabed rig with a standard CPTu cone developed at Ifremer (Sultan et al. 2007b; Garziglia et al. 2010), out of which two are used in this study (Fig. 9). Penfeld penetrometer provides a continuous measurement of the tip resistance $\left(\mathrm{q}_{\mathrm{c}}\right)$, sleeve friction $\left(\mathrm{f}_{\mathrm{s}}\right)$ and induced excess pore pressure $\left(\Delta_{\mathrm{u} 2}\right)$ at a standard rate of $2 \mathrm{~cm} \mathrm{~s}^{-1}$ down to $30 \mathrm{~m}$ below seafloor (mbsf). The corrected tip resistance $(\mathrm{qt})$ is calculated using the measured excess pore pressure $\left(\Delta_{\mathrm{u} 2}\right)$ values.

Values of peak undrained shear strength $(\mathrm{Su})$ were calculated from:

$S u=\frac{\left(q_{t}-\sigma_{v 0}\right)}{N_{k t}}$

Where $\sigma_{v 0}$ is vertical effective stress and $N_{k t}$ is a cone factor typically varying from 10 to 20 . Following Low et al. (2010), a minimum and a maximum value of Su were calculated using a $N_{k t}$ value of 10 and 20 .

Sensitivity values were derived using:

$S t=\frac{S u}{f_{s}}$

The overconsolidation ratio (OCR) can be calculated as the ratio between the preconsolidation stress $\left(\sigma_{\mathrm{p}}^{\prime}\right)$ and the vertical effective stress $\left(\sigma^{\prime} \mathrm{v}\right)$. 
$O C R=\frac{\sigma^{\prime} p}{\sigma^{\prime} v}$

\section{Results}

\section{Morphology and internal structure of seafloor instabilities in the GoL}

The GoL slope extends from water depths of 500 to $1200 \mathrm{~m}$. The slope is mainly characterised by three types of geomorphologic features: 1) sinuous elongated valleys that incise the seafloor down to several hundred meters interpreted as submarine canyons, 2) irregular, arcuate, curved breaks in the bathymetry interpreted as submarine landslide headwall scarps and 3) strike parallel linear breaks in the bathymetry interpreted as faults (Fig. 2).

The subsurface architecture of the study area is mainly characterised by parallel, wellstratified reflections related to the Petit Rhone channel levee complex (Fig. 3). Several steep dipping, low-amplitude anomalies interrupt the seismic reflections of the well-stratified sediments and interpreted as normal listric faults (Figs. 3,6). The lack of penetration of our seismic data until the base of faults refrains us from clearly imaging the origin of the faults. Nevertheless, dos Reis et al. (2005) demonstrated that a majority of listric faults in the GoL are rooted in the Messinian strata and are attributed to the gliding of post-Messinian sediments over the evaporite décollement surface. The architecture of the entire GoL slope is characterised by a morphology that is controlled by structural movements due to these listric faults. At times these faults reach the seafloor suggesting an ongoing fault activity that contributes to continuous steepening of the slope (e.g. Figs. 2, 3 and 6). Especially the southernmost fault in the seismic profile PSM2-117A shows a displacement of more than 150 ms creating a small-scale failure on the seafloor exposing the strata until Horizon H2' (Figs. 3 and 6).

Seismic profile AM-MED18 partially shows the internal structure of the ERIS (Fig. 4). A part of the source area shows two morphological steps of 30 and $70 \mathrm{~ms}$ height, which correspond to headwall scarps of the slide complex (Fig. 4). The basal surfaces of two failure steps of the ERIS imaged in the seismic data lie above the high-amplitude reflectors H2 and H3 (Fig. 4). Additionally, we observe a small MTD (Shallow MTD, Fig. 4) between horizon H3 and H4, similar to the ERIS, the basal surface of the shallow MTD lies on top of the high-amplitude reflector H4 (Fig. 4). 
The source area of the RWMTD is unfortunately not fully covered by our seismic data. Nevertheless, we observe a similar trend of failures in the area covered within the Western Slide Area. Seismic data show that similar to the ERIS, the basal shear surface of the RWMTD also lies above the high-amplitude reflector H1 (Figs. 5a, b). The RWMTD propagated translationally above the high-amplitude reflector $\mathrm{H}^{\prime}$ ' (marked with a black dashed line in Fig. 3) in the proximal part. After the erosion of the basal surface H1', further downslope the MTD propagated above reflector H1 (Fig. 3). The seismic profile PSM2-117A is located on the main pathway of the MTD (Fig. 2, 3). However, between offset 10 to $20 \mathrm{~km}$, where the slope angles become steeper, the RWMTD gradually thins to less than five ms in thickness. At places, especially between 15 to $20 \mathrm{~km}$ offset (Fig. 3) the RWMTD completely disappears, most likely due to steeper slope angles refraining deposition of failed sediments. Nevertheless, since the seismic profile is located at the main pathway of the MTD, it is likely that a significant amount of MTD propagated over horizon $\mathrm{H} 1$.

We observe a small-scale failure at 150 msbsf (ms below seafloor) between horizon $\mathrm{H} 4$ and H5 (Fig. 3). In the conventional HR seismic data, source area of this failure is defined by chaotic reflections typical of slump facies (Fig. 3). However, in the deep-towed seismic profile, the internal structure of the failure is imaged with unprecedented details (Fig. 6b, e). The source area of the failure is characterised by a sharp truncation of well-stratified sediments of around $30 \mathrm{~ms}$ thickness and translation of slide blocks with well-preserved internal reflections. It is interesting to note that the basal surface of this failure also occurs above the high-amplitude reflector H5 (Fig. 6b). The deposit area of the failure seems to be buttressed against the pre-existing strata, partially faulting and folding the strata. The resulting MTD from this failure seems to be of frontally emergent type that overflowed the pre-existing strata after generating a compressional zone by folding and faulting the strata (Fig. 6e). The source and the deposit area of the buried slope failure are vertically separated by $200 \mathrm{~ms}$, most likely due to fault displacement (Figs. 3, 6a).

The internal structure of the REMTD and RWMTD is defined by transparent acoustic facies in the conventional HR seismic profiles (Figs. 3, 4). Also in the deep-towed seismic profile, the REMTD shows transparent facies (Fig. 6a). However, about a km south of the fault scarp, within the hanging wall, we observe some km-scale irregular blocks of high-amplitude internal reflections within the MTD (Fig. 6d). These reflections do not seem to be associated with the processing artefacts, as the processing artefacts tend to mimic the seafloor. 
Therefore, we attribute these internal reflections to the slide blocks within the REMTD (Fig. $6 d)$.

\section{Sediment cores}

Three sediment cores were recovered on the western side of the Rhone submarine valley in the turbiditic levees (Figs. 6, 7). Cores PSM3-CS049 and PSM3-CS051 were recovered downslope and upslope the fault scarp, respectively. Core PSM3-CS050 was strategically retrieved at the fault scarp in order to sample the basal surface in the area of sediment removal due to fault reactivation (Fig. 6c). Lithological observations on the sediment cores may be classified into three lithofacies (L1 to L3; Fig. 7):

- Lithofacies L1 is composed of light grey foraminifera and calcareous nanoplankton oozes that correspond to hemipelagic-pelagic sedimentation during the sea level highstands (Badhani et al. 2019; Dennielou et al. 2019).

- Lithofacies L2 is composed of laminated clay with silt to very fine sand laminae interpreted as turbidites deposited by spillover from the Rhone valley (Dennielou $e t$ al. 2019).

- Lithofacies L3 is composed of stiff mud of generally higher bulk density than the background values (1.85-1.90 $\left.\mathrm{g} \mathrm{cm}^{3}\right)$. Based on the similarities observed in other studies in the same area (e.g. Bonnel et al. 2005; Dennielou et al. 2019, 2006; Lombo Tombo et al. 2015), we associate the lithofacies L3 to mass transport deposits. These lithofacies at times show colour banding corresponding to laminae and few silt layers characteristics of the Rhodanian fan lithofacies (Lombo Tombo et al. 2015; Dennielou et al. 2019).

\section{Core PSM3-CS051}

Core PSM3-CS051 is $22.65 \mathrm{~m}$ long and was collected at the footwall of the fault at a water depth of $2033 \mathrm{~m}$ (Fig. 7). The core is located in the area of a steep slope where we observe an absence of MTD in the seismic profile (Fig. 3). The substrate erosion (horizon H1') upslope allowed to penetrate high-amplitude reflector $\mathrm{H} 1$ (Figs. 3, 6). The uppermost $0.85 \mathrm{~m}$ of the core correspond to the lithofacies L1 showing lower gamma density and $\mathrm{Ca} / \mathrm{Fe}$ ratio than average values. Below $0.85 \mathrm{~m}$ until the bottom of the core, the core displays lithofacies L2, typically consisting of frequent alternating silty turbidites. The gamma density and $\mathrm{Ca} / \mathrm{Fe}$ ratio values are above average until $4.8 \mathrm{~m}$ (Fig. 7). Below $4.8 \mathrm{~m}$, we observe a sharp decrease 
in $\mathrm{Ca} / \mathrm{Fe}$ ratio, with values remaining constant until the bottom of the core, whereas the gamma density values are close to average $\left(1.8 \mathrm{~g} . \mathrm{cm}^{-3}\right)$. We observe an interval of finegrained material of dark grey colour with less frequent turbidites between $4.8 \mathrm{~m}$ and $9.5 \mathrm{~m}$. Upon correlation with seismic data (Fig. 6), we observe that this interval lies at the basal surface $\mathrm{H} 1$.

\section{Core PSM3-CSO50}

Core PSM3-CS050 (Fig. 7) is $11.26 \mathrm{~m}$ long and was collected at $2073 \mathrm{~m}$ water depth, at the fault scarp where the high-amplitude reflector $\mathrm{H} 2$ has been exposed due to removal of material related to faulting activity (Figs. 3 and 6). The uppermost $1.50 \mathrm{~m}$ of the core is composed of lithofacies L1, the gamma density and Vp values within this interval are lower than the background values $\left(1.8 \mathrm{~g} \mathrm{~cm}^{-3}\right.$ and $1550 \mathrm{~m} \mathrm{~s}^{-1}$, respectively). This unit shows $\mathrm{Ca} / \mathrm{Fe}$ ratios in the range of 3-5 (Fig. 7). From $1.5 \mathrm{~m}$ to $7 \mathrm{~m}$, the core is composed of lithofacies L2, where higher gamma density, $\mathrm{Vp}$ and $\mathrm{Ca} / \mathrm{Fe}$ ratios values than the background values are observed (Fig. 7). From $7 \mathrm{~m}$ to the bottom of the core, it presents light greyish clayey material typical of lithofacies L1. Between $9.5 \mathrm{~m}$ to $10.25 \mathrm{~m}$, we observe few thin-bedded turbidites (Fig. 7), which are consistent with the higher gamma density and Vp values. Otherwise, within this interval gamma density, $\mathrm{Vp}$ and $\mathrm{Ca} / \mathrm{Fe}$ ratio values are below average. Grain Size distribution (Fig. 8a) shows a presence of higher fine-grained material within the upper $1.5 \mathrm{~m}$. Between 1.5 and $7 \mathrm{~m}$, the grain-size distribution curve underlines a distribution of clayey to fine sand material in mostly equal percentage. Below $7 \mathrm{~m}$, the grain-size distribution plot shows a higher percentage of clay-sized particles, except between $9.5 \mathrm{~m}$ and $10.25 \mathrm{~m}$ where we observe a broad distribution of particle size from clay to silt, most likely due to the presence of thin-bedded turbidites (Fig. 7).

The peak shear strength (Fig. 8b) obtained from vane shear tests tends to increase linearly with depth, from $8 \mathrm{kPa}$ at the seafloor to $20 \mathrm{kPa}$ down to the base of the core. Peaks in shear strength at $7.5 \mathrm{~m}$ and $8.6 \mathrm{~m}$ interrupt this trend, as the shear strength increases to $23 \mathrm{kPa}$ and $44 \mathrm{kPa}$, respectively. When compared with the global shear strength trends for passive margins (Sawyer \& DeVore 2015), shear strengths measured on core PSM3-CS050 generally fall in the higher end of the plot, especially within the peaks in the shear strength at $7.5 \mathrm{~m}$ and between 8.6 to $10.5 \mathrm{~m}$ (Fig. $8 \mathrm{~b}$ ).

\section{Core PSM3-CS049}


Core PSM3-CS049 is $9.2 \mathrm{~m}$ long and was collected at $2096 \mathrm{~m}$ water depth at the footwall of the fault within the RWMTD (Fig. 2). The uppermost $0.80 \mathrm{~m}$ of sediments show clay-rich material of low gamma density and Vp (Fig. 7), that relate to lithofacies L1. Between 0.80 to $6.75 \mathrm{~m}$, we observe frequent silty turbidites embedded within hemipelagic sediments, which we consider corresponding to lithofacies L2. The gamma density and Vp values in this interval are higher as compared to lithofacies L1. Between $6.35-6.65 \mathrm{~m}$, we observe a fine to medium sand layer most likely related to an event bed such as a coarse-grained turbidite after the main failure event. This sand layer coincides with an interval of high values of gamma density $\left(2.05 \mathrm{~g} \mathrm{~cm}^{-3}\right)$ and $\mathrm{Vp}\left(>1.7 \mathrm{~m} \mathrm{~s}^{-1}\right.$, Fig. 7). Below $6.75 \mathrm{~m}$ to the bottom of the core, we observe folded coloured bands most likely associated with the RWMTD. We thus attribute this sediment interval to the lithofacies L3. The gamma density and Vp values within this interval are higher than in lithofacies L2. Radiocarbon dating at the base of lithofacies L2 in core PSM3-CS049 yields a $2 \sigma$ age between 21 and $21.7 \mathrm{ka} \mathrm{cal} \mathrm{BP,} \mathrm{with} \mathrm{an} \mathrm{average} \mathrm{median}$ age of $21.4 \mathrm{ka}$ cal. BP (at the peak of the LGM, Fig. 7; Tab. 1).

\section{In-situ geotechnical measurements}

\section{CPTu PMF-1102}

CPTu PMF-1102 (Fig. 9a) was performed in the area of sediment removal due to fault activity and coincides with core PSM3-CS050 (Figs. 6, 7). The uppermost $7.5 \mathrm{~m}$ of sediments show a quasi-linear increase in the corrected tip resistance $\left(\mathrm{q}_{\mathrm{t}}\right)$, sleeve friction $\left(\mathrm{f}_{\mathrm{s}}\right)$ and the induced excess pore pressure $\left(\Delta_{\mathrm{u} 2}\right)$, which correlates with values of reference CPTu measurements performed away from failure area (grey curve in Fig. 9). This sediment interval is described by a predominance of turbidites intercalated with hemipelagic sediments (Fig. 7). Below $7.5 \mathrm{~m}$, we observe a sharp increase in $\mathrm{q}_{\mathrm{t}}, \mathrm{f}_{\mathrm{s}}$ and $\Delta_{\mathrm{u} 2}$ values, as well as an increase in the shear strength profile (Fig. 9a). Interestingly, below $7.5 \mathrm{~m}$, until the bottom of the measurements, sediments are classified as fine-grained sediments, which is in agreement with the grain-size distribution curve of coinciding core PSM3-CS050 (Fig. 8a). Also, a peak in the over consolidation ratio (OCR) profile, is observed at the same depth, indicating that sediments are overconsolidated. Below $7.5 \mathrm{~m}$, OCR ratios decrease gradually, but remain above the value of 1 , indicating that sediments are slightly overconsolidated. Shear strength values also show increased values at the basal surface and there seems to be a good fit between the values obtained from CPT and laboratory vane shear test. The entire sensitivity 
profile is dominated by low to moderately sensitive sediments, especially at the basal surface sensitivity values decrease to a value of 2 .

\section{CPTu PMF-1104}

CPTu PMF-1104 (Fig. 9b) was performed within the RWMTD. Similar to CPTu PMF-1102, the uppermost $6.5 \mathrm{~m}$ of the profile is characterised by undeformed sediments, which show a quasi-linear increase in $\mathrm{q}_{\mathrm{t}}, \mathrm{f}_{\mathrm{s}}$ and $\Delta_{\mathrm{u} 2}$ values, typical for undisturbed seafloor sediments. Below $6.5 \mathrm{~m}$, and extending to the bottom of the profile, no clear trend can be seen. This could be attributed to the presence of silty layers within the MTD, which is evident with the drop of pore pressure where we observe peaks in the cone tip resistance (represented by grey intervals in Fig. 9b). We observe a quasi-linear increment in shear strength and sensitivity, while OCR values remain mostly constant until the bottom of the profile. In general, the RWMTD is slightly overconsolidated and show a normal sensitivity and shear strength as compared to the post-slide sediments.

\section{Discussion}

\section{Internal structure of mass movement products in the GoL}

Our data highlights recurring slope failures at different stratigraphic levels within PlioQuaternary sequence (Figs. 3-6) suggesting a long history of mass movements in the GoL (Badhani et al. 2019; Dennielou et al. 2019). Previous studies claimed a seismically homogeneous character of the surficial MTDs (Badhani et al. 2019; Dennielou et al. 2019). Newly collected deep-towed seismic data show few internal structures in the proximal part of the MTD at the hanging wall of the fault (Fig. 6). Coinciding in-situ measurements within the RWMTD confirm several closely spaced sediment layers with high tip resistance and coarsegrained beds suggested by negative peaks in pore pressure between $20-30 \mathrm{~m}$ (Fig. 9b), this is in contrast with homogenised material such as debris flow deposits which show an overall constant CPT profile with small scale irregularities (Garziglia et al. 2010). In addition, few contorted stratified layers have been observed in core PSM3-CS049 (Fig. 7). This suggests that RWMTD is not very homogenous as previously thought based on transparent seismic facies and that the degree of sediment disintegration in the proximal area is most likely lower than previously considered (Badhani et al. 2019; Dennielou et al. 2019). One can argue that the degree of sediment disintegration increases as the MTD propagated further downslope such as in the case of the Big'95 debris flow (Lastras et al. 2005). However, for the 
RWMTD, this could not be demonstrated due to lack of ground truth information in the distal part of the MTD.

In addition, in the subsurface we were able to image a small-scale landslide with intact slide blocks of $30 \mathrm{~ms}$ height that kept their stratigraphy after the sliding (Fig. 6b) that were represented as chaotic reflections in the conventional HR seismic data (Fig. 3). The intact slide blocks within the failure area suggest less deformation of strata during a local failure related to slope steepening due to halokinesis (dos Reis et al. 2005) that did not progress into a full dynamic slide (Alves et al. 2015). Therefore, we suggest that the chaotic reflections in the conventional seismic data can be imaged if the source and streamer are towed close to the seafloor in order to avoid diffractions from scattered blocks within the MTD.

Based on our observation, we suggest that the chaotic reflections in the MTDs (e.g. Figs. 3, $6 \mathrm{~b}, \mathrm{c}$ ) and transparent reflections in the debris flow deposits (e.g. RWMTD; Figs. 3, 6a) are generated due to lack of resolution of the conventional seismic data, which is not able to resolve scattered blocks embedded within the transported mass. This is important because with the previously available conventional seismic data most of the kinematic indicators (Frey-Martínez et al. 2006; Bull et al. 2009; Moscardelli \& Wood 2016) of the sliding are mostly ignored or poorly understood. Therefore, a better resolution of seismic data, such as deep-towed seismic data especially when coupled with in-situ measurements as presented in this study, will allow us to better understand large-scale, complex events in order to constrain seafloor instabilities in deep-water environments such as the GoL.

\section{Sedimentological, geotechnical and geophysical properties of basal surfaces}

With the help of combined geophysical, sedimentological and in-situ geotechnical properties of the GoL slope, we characterised the lithofacies within the study area. Mainly two types of genetically different sediments exist in the study area: 1) hemipelagic to pelagic fine-grained clay-rich sediments likely representing sea level high stand or interglacial period, 2) silty turbiditic sediments interbedded with hemipelagic intervals likely representing sea level lowstands or glacial and deglacial periods. The lithofacies L1 is characterised by fine-grained material of low $\mathrm{Ca} / \mathrm{Fe}$ ratios (Fig. 7). This lithofacies most likely deposited after the Holocene and represent present-day conditions (Dennielou et al. 2019). The glacial and deglacial conditions in the study area could be represented by the frequent occurrence of silty turbidites within lithofacies L2, showing that the river sources rapidly deposited these sediments close to the present-day shelf break. This lithofacies is represented by high $\mathrm{Ca} / \mathrm{Fe}$ ratios in cores 
PSM3-CS050 and 51 (Fig. 7). Radiocarbon dating on top of the MTD, within the turbiditic sediments shows that these lithofacies L1 and L2 (Fig 7) were deposited after the failure event during the LGM (Fig. 7). Most slope failures in the GoL occur bedding parallel over high amplitude reflectors, that are sometimes interpreted as impressions of condensed sections formed during the sea level highstands in the upper slope setting (Sierro et al. 2009). High-resolution seismic data clearly show that in the western side of the PRC the basal surface of the failure at the fault scarp lies below these units at a depth of $\sim 7.5 \mathrm{~m}$ (Fig. 6). At the basal surface in core PSM3-CS050, we observed sediment type similar to what is observed within lithofacies L1 (clay-rich hemipelagic sediments). This lithofacies as well shows more clayey sediments than the overlying turbiditic sequence (Fig. 8a), suggesting a less energetic environment or a time interval characterised by small volume turbidity currents that could be ascribed to highstand conditions. Also, the basal shear surface of the RWMTD in core PSM3-CS051 lies below lithofacies L1 and L2, although on a younger stratigraphic level (Fig. 7). Visual description of core PSM3-CS051 shows that the basal surface of the RWMTD is in a sediment interval with less turbidites if compared to overlying and underlying intervals (below 4.8 m, Fig. 7).

Core PSM3-CS051 and 50 are located in distinct stratigraphic units, core 51 penetrated basal surface of the RWMTD and core 50 penetrated the basal surface of the small failure on the fault scarp (Figs. 6, 7). With the help of gamma density, $\mathrm{Vp}$ and $\mathrm{Ca} / \mathrm{Fe}$ signatures of core PSM3-CS050 and 51, we were able to correlate the basal surface of the RWMTD and the failure at the fault scarp (Fig. 7). This allows us to extrapolate the detailed analysis on sediment core PSM3-CS050 to the Western Slide Area. It is interesting to note that both basal surfaces consist of higher fractions of clay-rich sediments. Similarly, on the eastern side of the PRC, successive headwall scarps of the ERIS and the shallow MTD took place over highamplitude reflectors (Fig. 4) that are interpreted to have deposited during highstands (Badhani et al. 2019). Sediment core PSM3-CS050 shows a good example where failure mostly affects turbiditic successions, even if the core is located in an area of limited sediment remobilisation (Fig. 6) and is not representative of large scale failures (e.g. REMTD and RWMTD). We observe a similar process of failure over the high-amplitude reflectors throughout the Plio-Quaternary strata in the GoL. Therefore, it is likely that the failure surfaces in the GoL are influenced by climatic forcing related to Milankovitch cyclicity tuning the number and volume of turbiditic flows in the Rhone system and forming surfaces of significantly different mechanical properties in the sedimentary column. The inference of 
increased turbiditic deposits during glacial and deglacial times is based on evidence from the nearby Var turbiditic system (Jorry et al. 2011). We suggest that this could also be extrapolated to the entire GoL where a majority of failures took place bedding parallel over clay-rich sediments deposited during the highstand periods (Figs. 3-6).

Many studies have pointed out the role of lithological heterogeneities in enhancing seafloor instabilities (e.g. Laberg \& Camerlenghi 2008; L'Heureux et al. 2012). We point out that the interface between clay-rich hemipelagic successions and overlying turbiditic sequences is critical. In-situ geotechnical measurements show that the sediments below the basal surface of the failure on the fault scarp show higher shear strength, OCR, and low sensitivity values than the background values (Fig. 9a, b). This is consistent with laboratory vane shear measurements for the basal surface of the failure at the fault scarp (Fig. 8). However, it should be noted that these elevated values of shear strength measurement could be due to the removal of sediments above the basal surface during the failure at the fault scarp.

Nevertheless, several processes can induce slope instabilities where lithological heterogeneity within the strata exists such as liquefaction potential of coarse-grained material and excess pore pressure generation in presence of very high sedimentation rates such as in the GoL during several lowstands (Kettner \& Syvitski 2009; Sierro et al. 2009; Lombo Tombo et al. 2015; Dennielou et al. 2019). Dan et al. (2009) showed that coarser-grained materials (such as turbidites) are prone to liquefaction even in case of a mild seismic loading. Lafuerza et al. (2014) and Hornbach et al. (2015) demonstrated that in a sediment column, excess pore pressure resides in coarse-grained intervals while fine-grained intervals show very low permeability and act as seals generating weak layers at the boundary between coarse-grained and fine-grained sediments. This may potentially imply that also in deep-water environments such as the GoL, even if not significant, lithological heterogeneity exists and most likely control the localisation of potential weak layers. This may explain the recurrence of failures over clay-rich hemipelagic sediments identified at several stratigraphic levels in the GoL (Figs. 3-6).

Variations in sediment grain-size also occur in multiple settings around the globe e.g. volcanic flanks (Lafuerza et al. 2014; Hornbach et al. 2015; Brunet et al. 2016); passive margins (Sawyer et al. 2009); glacial margins (Laberg \& Camerlenghi 2008). With the example provided from the GoL, we further support the evidence that lithological heterogeneity within the sediment successions is a key to localisation of seafloor instability. 
The identification of this stratigraphic control as a major predisposing factor for seafloor instability allows a better assessment by understanding the causes of recurrent failures.

\section{Conclusions}

The GoL is a passive margin of about $200 \mathrm{~km}$ length and $70 \mathrm{~km}$ width with main sediment supply from the Rhone River supplying Alpine sediments to the Rhone delta. Previous studies highlighted two large surficial submarine landslides with resulting volumes exceeding $100 \mathrm{~km}^{3}$. We presented here the internal structure of mass transport deposit and small-scale slope failures with unprecedented details using newly available very high-resolution deeptowed seismic data for the first time in the GoL. We showed an example of failure that consisted of slided blocks, folded and faulted strata with preserved stratigraphy that were previously imaged as "transparent" or "chaotic" reflections in the conventional reflection seismic data. The combination of deep-towed seismic, sedimentological data and in-situ measurements allowed us to analyse the basal surface of the slope failures in greater detail. We showed that the basal surfaces of the recurring slope failures consist of clay-rich sediments as compared to turbiditic deposits that dominate the GoL margin. It is evident that greater degree of lithological heterogeneity promotes slope failure in the GoL most likely related to higher liquefaction potential of coarser-grained material, excess pore pressure and maybe resulting variation in sediment strength. However, further analysis is necessary to confirm if these factors influence slope stability in the GoL.

\section{Acknowledgements}

We thank the captains, crew and science parties of the PRISME-2 and PRISME-3 campaigns onboard R/V L'Atalante and R/V Pourquoi pas?, respectively for their support during the campaigns. The PhD of Shray Badhani is funded by the European Union's Horizon 2020 research and innovation programme under the Marie-Skłodowska-Curie grant via project ITN SLATE (grant agreement No. 721403). Elena Martinez Planchart (ICM, Barcelona) is thanked for carrying out grain-size analysis on sediment core PSM3-CS050. We thank Nabil Sultan for discussions on CPTu data interpretation. We are also grateful to reviewers Samantha Clarke and Sara Lafuerza and editor Lawrence Amy for providing insightful reviews that significantly improved this manuscript.

\section{References}

Alves, T.M. 2015. Submarine slide blocks and associated soft-sediment deformation in deep- 
water basins: A review. Marine and Petroleum Geology, 67, 262-285, https://doi.org/10.1016/j.marpetgeo.2015.05.010.

Badhani, S., Cattaneo, A., et al. 2019. Morphology of retrogressive failures in the Eastern Rhone Interfluve during the Last Glacial Maximum (Gulf of Lions, Western Mediterranean). Geomorphology, https://doi.org/10.1016/j.geomorph.2019.106894.

Baeten, N.J., Laberg, J.S., et al. 2014. Origin of shallow submarine mass movements and their glide planes-Sedimentological and geotechnical analyses from the continental slope off northern Norway. Journal of Geophysical Research: Earth Surface, 119, 2335-2360, https://doi.org/10.1002/2013JF003068.

Bassetti, M.A., Berné, S., et al. 2008. The 100-ka and rapid sea level changes recorded by prograding shelf sand bodies in the Gulf of Lions (western Mediterranean Sea). Geochemistry, Geophysics, Geosystems, 9, 11, https://doi.org/10.1029/2007GC001854.

Bellaiche, G., Coutellier, V. \& Droz, L. 1986. Seismic evidence of widespread mass transport deposits in the Rhône deep-sea fan: Their role in the fan construction. Marine Geology, 71, 327-340, https://doi.org/10.1016/0025-3227(86)90076-9.

Berné, S., Satra, C., et al. 2002. Carte morpho-bathymétrique du Golfe du Lion, notice explicative. Ifremer, Brest, 48 .

Berné, S., Jouet, G., Bassetti, M.A., Dennielou, B. \& Taviani, M. 2007. Late Glacial to Preboreal sea-level rise recorded by the Rhône deltaic system (NW Mediterranean). Marine Geology, 245, 65-88, https://doi.org/10.1016/j.margeo.2007.07.006.

Bonnel, C., Dennielou, B., Droz, L. \& Mulder, T. 2005. Architecture and depositional pattern of the Rhône Neofan and recent gravity activity in the Gulf of Lions (western Mediterranean). Marine and Petroleum Geology, 22, 827-843, https://doi.org/10.1016/J.MARPETGEO.2005.03.003.

Brooks, G.R. 2016. Evidence of late glacial paleoseismicity from submarine landslide deposits within Lac Dasserat, northwestern Quebec, Canada. Quaternary Research, 86, 184-199, https://doi.org/10.1016/J.YQRES.2016.06.005.

Brunet, M., Le Friant, A., et al. 2016. Composition, geometry, and emplacement dynamics of a large volcanic island landslide offshore Martinique: From volcano flank-collapse to 
seafloor sediment failure? Geochemistry, Geophysics, Geosystems, 17, 699-724, https://doi.org/10.1002/2015GC006034.

Bryn, P., Solheim, A., et al. 2003. The Storegga Slide Complex; Repeated Large Scale Sliding in Response to Climatic Cyclicity. Springer, Dordrecht, 215-222., https://doi.org/10.1007/978-94-010-0093-2_24.

Bryn, P., Berg, K., Forsberg, C.F., Solheim, A. \& Kvalstad, T.J. 2005. Explaining the Storegga Slide. Marine and Petroleum Geology, 22, 11-19, https://doi.org/10.1016/j.marpetgeo.2004.12.003.

Bull, S., Cartwright, J. \& Huuse, M. 2009. A review of kinematic indicators from masstransport complexes using 3D seismic data. Marine and Petroleum Geology, 26, 11321151, https://doi.org/10.1016/J.MARPETGEO.2008.09.011.

Carvajal, M., Araya-Cornejo, C., Sepúlveda, I., Melnick, D. \& Haase, J.S. 2019. Nearly Instantaneous Tsunamis Following the Mw 7.5 2018 Palu Earthquake. Geophysical Research Letters, 2019GL082578, https://doi.org/10.1029/2019GL082578.

Cattaneo, A. 2013a. PRISME 2 cruise, RV L'Atalante, https://doi.org/10.17600/13010050.

Cattaneo, A. 2013b. PRISME 3 Cruise, RV Pourquoi Pas?, https://doi.org/10.17600/13030060.

Damuth, J.E. 1980. Use of high-frequency $(3.5-12 \mathrm{kHz})$ echograms in the study of nearbottom sedimentation processes in the deep-sea: A review. Marine Geology, 38, 51-75, https://doi.org/10.1016/0025-3227(80)90051-1.

Dan, G., Sultan, N. \& Savoye, B. 2007. The 1979 Nice harbour catastrophe revisited: Trigger mechanism inferred from geotechnical measurements and numerical modelling. Marine Geology, 245, 40-64, https://doi.org/10.1016/J.MARGEO.2007.06.011.

Dan, G., Sultan, N., Savoye, B., Deverchere, J. \& Yelles, K. 2009. Quantifying the role of sandy-silty sediments in generating slope failures during earthquakes: example from the Algerian margin. International Journal of Earth Sciences, 98, 769-789, https://doi.org/10.1007/s00531-008-0373-5.

Dennielou, B., Huchon, A., Beaudouin, C. \& Berné, S. 2006. Vertical grain-size variability within a turbidite levee: Autocyclicity or allocyclicity? A case study from the Rhône 
neofan, Gulf of Lions, Western Mediterranean. Marine Geology, 234, 191-213, https://doi.org/10.1016/J.MARGEO.2006.09.019.

Dennielou, B., Jégou, I., et al. 2019. Major modification of sediment routing by a large Mass Transport Deposit in the Gulf of Lions (Western Mediterranean). Marine Geology, 411, 1-20, https://doi.org/10.1016/J.MARGEO.2019.01.011.

dos Reis, A.T., Gorini, C. \& Mauffret, A. 2005. Implications of salt-sediment interactions on the architecture of the Gulf of Lions deep-water sedimentary systems-western Mediterranean Sea. Marine and Petroleum Geology, 22, 713-746, https://doi.org/10.1016/J.MARPETGEO.2005.03.006.

Droz, L. \& Bellaiche, G. 1985. Rhone deep-sea fan: morphostructure and growth pattern. AAPG Bulletin, 69, 460-479.

Droz, L., Kergoat, R., Cochonat, P. \& Berné, S. 2001. Recent sedimentary events in the western Gulf of Lions (Western Mediterranean). Marine Geology, 176, 23-37, https://doi.org/10.1016/S0025-3227(01)00147-5.

Droz, L., dos Reis, A.T., Rabineau, M., Berné, S. \& Bellaiche, G. 2006. Quaternary turbidite systems on the northern margins of the Balearic Basin (Western Mediterranean): A synthesis. Geo-Marine Letters, 26, 347-359, https://doi.org/10.1007/s00367-006-00440.

Frey-Martínez, J., Cartwright, J. \& James, D. 2006. Frontally confined versus frontally emergent submarine landslides: A 3D seismic characterisation. Marine and Petroleum Geology, 23, 585-604, https://doi.org/10.1016/j.marpetgeo.2006.04.002.

Garziglia, S., Sultan, N., et al. 2010. Identification of Shear Zones and Their Causal Mechanisms Using a Combination of Cone Penetration Tests and Seismic Data in the Eastern Niger Delta. Submarine Mass Movements and Their Consequences: Advances in Natural and Technological Hazards Research, Volume 28, 28, 55-77.

Hampton, M.A., Lee, H.J. \& Locat, J. 1996. Submarine landslides. Reviews of Geophysics, 34, 33-59, https://doi.org/10.1029/95RG03287.

Heidarzadeh, M., Muhari, A. \& Wijanarto, A.B. 2018. Insights on the Source of the 28 September 2018 Sulawesi Tsunami, Indonesia Based on Spectral Analyses and 
Numerical Simulations. Pure and Applied Geophysics, 1-19, https://doi.org/10.1007/s00024-018-2065-9.

Hornbach, M.J., Manga, M., et al. 2015. Permeability and pressure measurements in Lesser Antilles submarine slides: Evidence for pressure-driven slow-slip failure. Journal of Geophysical Research: Solid Earth, 120, 7986-8011, https://doi.org/10.1002/2015JB012061.

Hsu, K.J. 1973. The origin of the Mediterranean evaporites. Initial reports of the deep sea drilling project, 13, 1203-1231.

Jorry, S.J., Jégou, I., Emmanuel, L., Silva Jacinto, R. \& Savoye, B. 2011. Turbiditic levee deposition in response to climate changes: The Var Sedimentary Ridge (Ligurian Sea). Marine Geology, 279, 148-161, https://doi.org/10.1016/j.margeo.2010.10.021.

Jouet, G. 2007. Enregistrements stratigraphiques des cycles climatiques et glacio-eustatiques du Quaternaire terminal. 433.

Ker, S., Marsset, B., Garziglia, S., Le Gonidec, Y., Gibert, D., Voisset, M. \& Adamy, J. 2010. High-resolution seismic imaging in deep sea from a joint deep-towed/OBH reflection experiment: Application to a Mass Transport Complex offshore Nigeria. Geophysical Journal International, 182, 1524-1542, https://doi.org/10.1111/j.1365246X.2010.04700.x.

Kettner, A.J. \& Syvitski, J.P.M. 2009. Fluvial responses to environmental perturbations in the Northern Mediterranean since the Last Glacial Maximum. Quaternary Science Reviews, 28, 2386-2397, https://doi.org/10.1016/J.QUASCIREV.2009.05.003.

Kvalstad, T.J., Nadim, F., Kaynia, A.M., Mokkelbost, K.H. \& Bryn, P. 2005. Soil conditions and slope stability in the Ormen Lange area. Marine and Petroleum Geology, 22, 299310, https://doi.org/10.1016/j.marpetgeo.2004.10.021.

L'Heureux, J.-S., Longva, O., et al. 2012. Identification of Weak Layers and Their Role for the Stability of Slopes at Finneidfjord, Northern Norway. In: Submarine Mass Movements and Their Consequences. Dordrecht, Springer Netherlands, 321-330., https://doi.org/10.1007/978-94-007-2162-3_29.

Laberg, J.S. \& Camerlenghi, A. 2008. Chapter 25 The Significance of Contourites for 
Submarine Slope Stability, First Edit. Elsevier, https://doi.org/10.1016/S00704571(08)10025-5.

Lafuerza, S., Le Friant, A., et al. 2014. Geomechanical Characterization of Submarine Volcano-Flank Sediments, Martinique, Lesser Antilles Arc. Springer, Cham, 73-81., https://doi.org/10.1007/978-3-319-00972-8_7.

Lastras, G., Canals, M., Urgeles, R., Hughes-Clarke, J.E. \& Acosta, J. 2004. Shallow slides and pockmark swarms in the Eivissa Channel, western Mediterranean Sea. Sedimentology, 51, 837-850, https://doi.org/10.1111/j.1365-3091.2004.00654.x.

Lastras, G., De Blasio, F. V., Canals, M. \& Elverhoi, A. 2005. Conceptual and Numerical Modeling of the BIG'95 Debris Flow, Western Mediterranean Sea. Journal of Sedimentary Research, 75, 784-797, https://doi.org/10.2110/jsr.2005.063.

Le Friant, A., Ishizuka, O., et al. 2015. Submarine record of volcanic island construction and collapse in the Lesser Antilles arc: First scientific drilling of submarine volcanic island landslides by IODPExpedition 340. Geochemistry, Geophysics, Geosystems, 16, 420442, https://doi.org/10.1002/2014GC005652.

Locat, J., Leroueil, S., Locat, A. \& Lee, H. 2014. Weak Layers: Their Definition and Classification from a Geotechnical Perspective. Springer, Cham, 3-12., https://doi.org/10.1007/978-3-319-00972-8_1.

Lofi, J., Rabineau, M., et al. 2003. Plio-Quaternary prograding clinoform wedges of the western Gulf of Lion continental margin (NW Mediterranean) after the Messinian Salinity Crisis. Marine Geology, 198, 289-317, https://doi.org/10.1016/S00253227(03)00120-8.

Lombo Tombo, S., Dennielou, B., et al. 2015. Sea-level control on turbidite activity in the Rhone canyon and the upper fan during the Last Glacial Maximum and Early deglacial. Sedimentary Geology, https://doi.org/10.1016/j.sedgeo.2015.04.009.

Low, H.E., Lunne, T., Andersen, K.H., Sjursen, M.A., Li, X. \& Randolph, M.F. 2010. Estimation of intact and remoulded undrained shear strengths from penetration tests in soft clays. Géotechnique, 60, 843.

Marsset, B., Menut, E., et al. 2014. Deep-towed high resolution multichannel seismic 
imaging. Deep-Sea Research Part I: Oceanographic Research Papers, 93, 83-90, https://doi.org/10.1016/j.dsr.2014.07.013.

Masson, D., Harbitz, C.., Wynn, R.., Pedersen, G. \& Løvholt, F. 2006. Submarine landslides: processes, triggers and hazard prediction. Philosophical Transactions of the Royal Society A: Mathematical, Physical and Engineering Sciences, 364, 2009-2039, https://doi.org/10.1098/rsta.2006.1810.

Micallef, A., Mountjoy, J.J., Canals, M. \& Lastras, G. 2012. Deep-Seated Bedrock Landslides and Submarine Canyon Evolution in an Active Tectonic Margin: Cook Strait, New Zealand. In: Submarine Mass Movements and Their Consequences. Dordrecht, Springer Netherlands, 201-212., https://doi.org/10.1007/978-94-007-2162-3_18.

Miramontes, E., Sultan, N., Garziglia, S., Jouet, G., Pelleter, E. \& Cattaneo, A. 2018. Altered volcanic deposits as basal failure surfaces of submarine landslides. Geology, 46, 663666, https://doi.org/10.1130/G40268.1.

Moernaut, J., Van Daele, M., et al. 2017. Lacustrine turbidites produced by surficial slope sediment remobilization: A mechanism for continuous and sensitive turbidite paleoseismic records. Marine Geology, 384, 159-176, https://doi.org/10.1016/J.MARGEO.2015.10.009.

Moore, J.G., Clague, D.A., Holcomb, R.T., Lipman, P.W., Normark, W.R. \& Torresan, M.E. 1989. Prodigious submarine landslides on the Hawaiian Ridge. Journal of Geophysical Research, 94, 17465, https://doi.org/10.1029/JB094iB12p17465.

Moscardelli, L. \& Wood, L. 2016. Morphometry of mass-transport deposits as a predictive tool. Bulletin of the Geological Society of America, 128, 47-80, https://doi.org/10.1130/B31221.1.

Ogata, K., Pini, G.A., et al. 2014. High-Resolution Studies of Mass Transport Deposits: Outcrop Perspective for Understanding Modern Submarine Slope Failure and Associated Natural Hazards. In: Engineering Geology for Society and Territory Volume 4. Cham, Springer International Publishing, 209-213., https://doi.org/10.1007/978-3-319-08660-6_40.

Ogata, K., Pini, G.A., Festa, A., Pogačnik, Ž. \& Lucente, C.C. 2016. Meso-Scale Kinematic Indicators in Exhumed Mass Transport Deposits: Definitions and Implications. Springer, 
Cham, 461-468., https://doi.org/10.1007/978-3-319-20979-1_46.

Posamentier, H.W. \& Kolla, V. 2003. Seismic Geomorphology and Stratigraphy of Depositional Elements in Deep-Water Settings. Journal of Sedimentary Research, 73, 367-388, https://doi.org/10.1306/111302730367.

Praet, N., Moernaut, J., et al. 2017. Paleoseismic potential of sublacustrine landslide records in a high-seismicity setting (south-central Alaska). Marine Geology, 384, 103-119, https://doi.org/10.1016/J.MARGEO.2016.05.004.

Principaud, M., Mulder, T., Gillet, H. \& Borgomano, J. 2014. Large-scale carbonate submarine mass-wasting along the northwestern slope of the Great Bahama Bank (Bahamas): Morphology, architecture, and mechanisms, https://doi.org/10.1016/j.sedgeo.2014.10.008.

Rabineau, M., Berné, S., Ledrezen, É., Lericolais, G., Marsset, T. \& Rotunno, M. 1998. 3D architecture of lowstand and transgressive Quaternary sand bodies on the outer shelf of the Gulf of Lion, France. Marine and Petroleum Geology, 15, 439-452, https://doi.org/10.1016/S0264-8172(98)00015-4.

Rabineau, M., Berné, S., et al. 2005. Sedimentary sequences in the Gulf of Lion: A record of 100,000 years climatic cycles. Marine and Petroleum Geology, 22, 775-804, https://doi.org/10.1016/j.marpetgeo.2005.03.010.

Rabineau, M., Droz, L. \& Aslanian, D. 2013. AM-MED-1 Cruise, RV Le Surô̂t, https://doi.org/10,17600/18000821.

Reimer, P.J., Edouard Bard, B., Alex Bayliss, B., Warren Beck, B.J., Paul Blackwell, B.G. \& Christopher Bronk Ramsey, B. 2013. IntCal13 and Marine13 radiocarbon age calibration curves 0-50,000 years cal bp. Radiocarbon, 55, 1869-1887.

Robertson, P.K. 1990. Soil classification using the cone penetration test. Canadian Geotechnical Journal, 27, 151-158, https://doi.org/10.1139/t90-014.

Roveri, M., Lugli, S., Manzi, V. \& Schreiber, B.C. 2008. The Messinian Sicilian stratigraphy revisited: new insights for the Messinian salinity crisis. Terra Nova, 20, 483-488, https://doi.org/10.1111/j.1365-3121.2008.00842.x.

Sassa, S. \& Takagawa, T. 2019. Liquefied gravity flow-induced tsunami: first evidence and 
comparison from the 2018 Indonesia Sulawesi earthquake and tsunami disasters. Landslides, 16, 195-200, https://doi.org/10.1007/s10346-018-1114-х.

Sawyer, D.E. \& DeVore, J.R. 2015. Elevated shear strength of sediments on active margins: Evidence for seismic strengthening. Geophysical Research Letters, 42, 10,216-10,221, https://doi.org/10.1002/2015GL066603.

Sawyer, D.E., Flemings, P.B., Dugan, B. \& Germaine, J.T. 2009. Retrogressive failures recorded in mass transport deposits in the Ursa Basin, Northern Gulf of Mexico. 114, https://doi.org/10.1029/2008JB006159.

Sierro, F.J., Andersen, N., et al. 2009. Phase relationship between sea level and abrupt climate change. Quaternary Science Reviews, 28, 2867-2881, https://doi.org/10.1016/j.quascirev.2009.07.019.

Silva, C.G., Araújo, E., Reis, A.T., Perovano, R., Gorini, C., Vendeville, B.C. \& Albuquerque, N. 2010. Megaslides in the Foz do Amazonas Basin, Brazilian Equatorial Margin. In: Mosher, D. C., Shipp, R. C., Moscardelli, L., Chaytor, J. D., Baxter, C. D. P., Lee, H. J. \& Urgeles, R. (eds) Submarine Mass Movements and Their Consequences. Dordrecht, Springer Netherlands, 581-591., https://doi.org/10.1007/978-90-481-30719_47.

St-Onge, G., Mulder, T., Piper, D.J.W., Hillaire-Marcel, C. \& Stoner, J.S. 2004. Earthquake and flood-induced turbidites in the Saguenay Fjord (Québec): a Holocene paleoseismicity record. Quaternary Science Reviews, 23, 283-294, https://doi.org/10.1016/J.QUASCIREV.2003.03.001.

Stuiver, M., Reimer, P.J. \& Reimer, R.W. 2017. Calib 7.1 [www program].

Sultan, N., Gaudin, M., Berne, S., Canals, M.M., Urgeles, R. \& Lafuerza, S. 2007a. Analysis of slope failures in submarine canyon heads: An example from the Gulf of Lions. Journal of Geophysical Research: Earth Surface, 112, F01009, https://doi.org/10.1029/2005JF000408.

Sultan, N., Voisset, M., Marsset, B., Marsset, T., Cauquil, E. \& Colliat, J.-L. 2007b. Potential role of compressional structures in generating submarine slope failures in the Niger Delta. Marine Geology, 237, 169-190, https://doi.org/10.1016/J.MARGEO.2006.11.002. 
Talling, P., Clare, M., Urlaub, M., Pope, E., Hunt, J. \& Watt, S. 2014. Large Submarine Landslides on Continental Slopes: Geohazards, Methane Release, and Climate Change. Oceanography, 27, 32-45, https://doi.org/10.5670/oceanog.2014.38.

Tappin, D.R., Matsumoto, T., et al. 1999. Sediment slump likely caused 1998 Papua New Guinea tsunami. Eos, Transactions American Geophysical Union, 80, 329, https://doi.org/10.1029/99EO00241.

Tesson, M. \& Gensous, B. 1998. L'enregistrement des cycles climatiques et eustatiques quaternaires de marges récentes du bassin Nord-Méditerranéen. Comptes Rendus de l'Académie des Sciences - Series IIA - Earth and Planetary Science, 326, 121-127, https://doi.org/10.1016/S1251-8050(97)87456-3.

Torres, J., Droz, L., Savoye, B., Terentieva, E., Cochonat, P., Kenyon, N.H. \& Canals, M. 1997. Deep-sea avulsion and morphosedimentary evolution of the Rhône Fan Valley and Neofan during the Late Quaternary (north-western Mediterranean Sea). Sedimentology, 44, 457-477, https://doi.org/10.1046/j.1365-3091.1997.d01-36.x.

Urgeles, R., Canals, M., Baraza, J., Alonso, B. \& Masson, D. 1997. The most recent megalandslides of the Canary Islands: El Golfo debris avalanche and Canary debris flow, west El Hierro Island. Journal of Geophysical Research: Solid Earth, 102, 2030520323, https://doi.org/10.1029/97JB00649.

Urlaub, M., Geersen, J., Krastel, S. \& Schwenk, T. 2018. Diatom ooze: Crucial for the generation of submarine mega-slides? Geology, 46, 2-5, https://doi.org/10.1130/G39892.1.

\section{List of figures}

Figure 1. EMODnet bathymetric map of the GoL margin highlighting the distribution of main sedimentary and mass movement features (black lines: headwall of submarine landslides and mass transport deposits; yellow line: present-day thalweg of the Petit Rhone Canyon; green lines: thalwegs of the main submarine canyons; blue line: shelf break; white dashed polygon: raft (salt) domain dominated by listric faults). Abbreviations for the GoL canyons (Berné et al. 2002), from West to East- CC: Cap de Creus, LD: Lacaze Duthier, P: Pruvost, Bc: Bourcart, He: Herault, S: Sète, CL: Catherine Laurence, M: Marti, PR: PetitRhone, GR: Grand-Rhone, Ms: Marseille, PL: Planier, C: Cassidaigne. REMTD: Rhone 
Eastern Mass Transport Deposit, RWMTD: Rhone Western Mass Transport Deposit. Limits of sedimentary bodies are from Droz et al. (2006); Raft domain dominated by active and buried listric faults are from dos Reis et al. (2005).

Figure 2. High-resolution multibeam bathymetric map of the source area of the landslides (see Fig. 1 for location). Landslide headwalls are highlighted with dashed black lines and active faults related to Messinian salt are highlighted with blue lines. Solid black lines represent locations of the seismic profiles shown in Figures 3, 4 and 5a and b. In the inset, black circles and light blue rectangles respectively represent the locations of the sediment cores and the in-situ geotechnical measurements acquired during PRISME3 cruise (see Figs. $7,9)$.

Figure 3. NS oriented seismic profile crossing the western slide area showing the internal architecture of the study area. Solid black lines represent prominent faults imaged in the seismic profile. The seismic stratigraphy of the study area is highlighted by seven key highamplitude reflectors (H1 to H6). See Figure 6 for a focus on the central part of the profile (Offset 17-21km).

Figure.4. NNW-SSE oriented Seismic profile AM-MED018 crossing the eastern part of the ERIS. It illustrates two headwall scarps (HS2\& HS3) showing particularly sharp truncation and transparent unit interpreted as a buried MTD. Headwall scarps of the landslides are represented by sharp truncations of well-stratified sediments disappearing downslope. The basal surface of the MTD corresponds to the prolongation of a sharp contact between underlying low amplitude reflectors and overlying high amplitude reflectors.

Fig. 5a and $b$ Seismic profiles showing examples of headwall scarps and other erosional features within the western slide area, similar to the ERIS, the basal surface of the landslides coincide with the transition between underlying low and overlying high-amplitude reflectors.

Figure. 6. (a) NS oriented very high-resolution seismic profile corresponding to a focus of Figure 3 (see location on Fig. 1). The internal architecture of the study area is dominated by well-stratified reflectors sometimes interrupted downstream headwall scarps. Note the presence of internal reflections within the transparent RWMTD facies. Red and blue rectangles show the location of sediment cores and in-situ measurements, respectively, (b) blow-up of the small slope failure shows $\sim 30 \mathrm{~ms}$ high slide blocks with intact internal reflections. Note that seismic facies in this area was previously interpreted as chaotic on the 
conventional high-resolution seismic data, (c) zoom at the fault scarp showing the location of core PSM3-CS050, (d) zoom of the RWMTD at the hanging wall showing slide blocks within the MTD and (e) blow-up of the deposit area of the slope failure, which is identified by frontal buttressing of the slide deposit against the unfailed material, as shown by folded strata in the frontal part.

Figure 7. Gamma density, $\mathrm{Vp}, \mathrm{Ca} / \mathrm{Fe}$ ratio, sediment photos and lithofacies of sediment cores (from left to right, PSM3-CS051, 50 and 49) collected in the western slide area and the RWMTD. See Fig. 6 for core locations.

Figure 8. (a) grain-size distribution and (b) Vane shear strength measurements of core PSM3CS050.

Figure 9. a and b from left to right: corrected cone resistance $\left(\mathrm{q}_{\mathrm{t}}\right)$ and reference $\mathrm{q}_{\mathrm{t}}$ (grey line), sleeve friction $\left(\mathrm{f}_{\mathrm{s}}\right)$, excess pore pressure $\left(\Delta_{\mathrm{u} 2}\right)$, peak undrained shear strength $(\mathrm{Su})$ from CPTu (min grey lines and max black lines) and from laboratory vane shear test on core PSM3CS050 (red diamonds only for Figure 9a, undrained shear strength (Su), sensitivity (St) and overconsolidation ratio (OCR) and soil type from CPTu. Soil type from CPTu data is derived from $\mathrm{Q}_{\mathrm{t}} / \mathrm{F}_{\mathrm{r}}$, where soil type 1 = sensitive, fine-grained, 2 = organic soils-peats, 3 = clay to silty clay, 4 = clayey silt to silty clay and 5 = silty sand to sandy silt (after Robertson 1990): The dashed black line represent the basal surface of the small failure and the green dashed line represent the RWMTD top. See Fig. 6 for CPTu locations.

\section{List of tables}

Table 1. Radiocarbon dating carried out on sediment core PSM3-CS049. 


\begin{tabular}{lllll}
\hline Core-section-depth $(\mathrm{m})$ & $\begin{array}{l}\text { Lab reference } \\
\text { no. }\end{array}$ & 14C age & $\begin{array}{l}\text { Calibrated } \\
\text { age }\end{array}$ & $\begin{array}{l}\text { Sampled } \\
\text { material }\end{array}$ \\
\hline PSM3-CS049-S07-6.12 & 510580 & $17540+/-50 \mathrm{BP}$ & $\begin{array}{l}20935- \\
20295\end{array}$ & G. bulloides \\
& & $18100+/-60 \mathrm{BP}$ & $\begin{array}{l}21723- \\
20974\end{array}$ & G. bulloides \\
PSM3-CS049-S07-6.25 & 508505 & & $21785-$ & G. bulloides \\
& & $18150+/-60 \mathrm{BP}$ & 21038 &
\end{tabular}




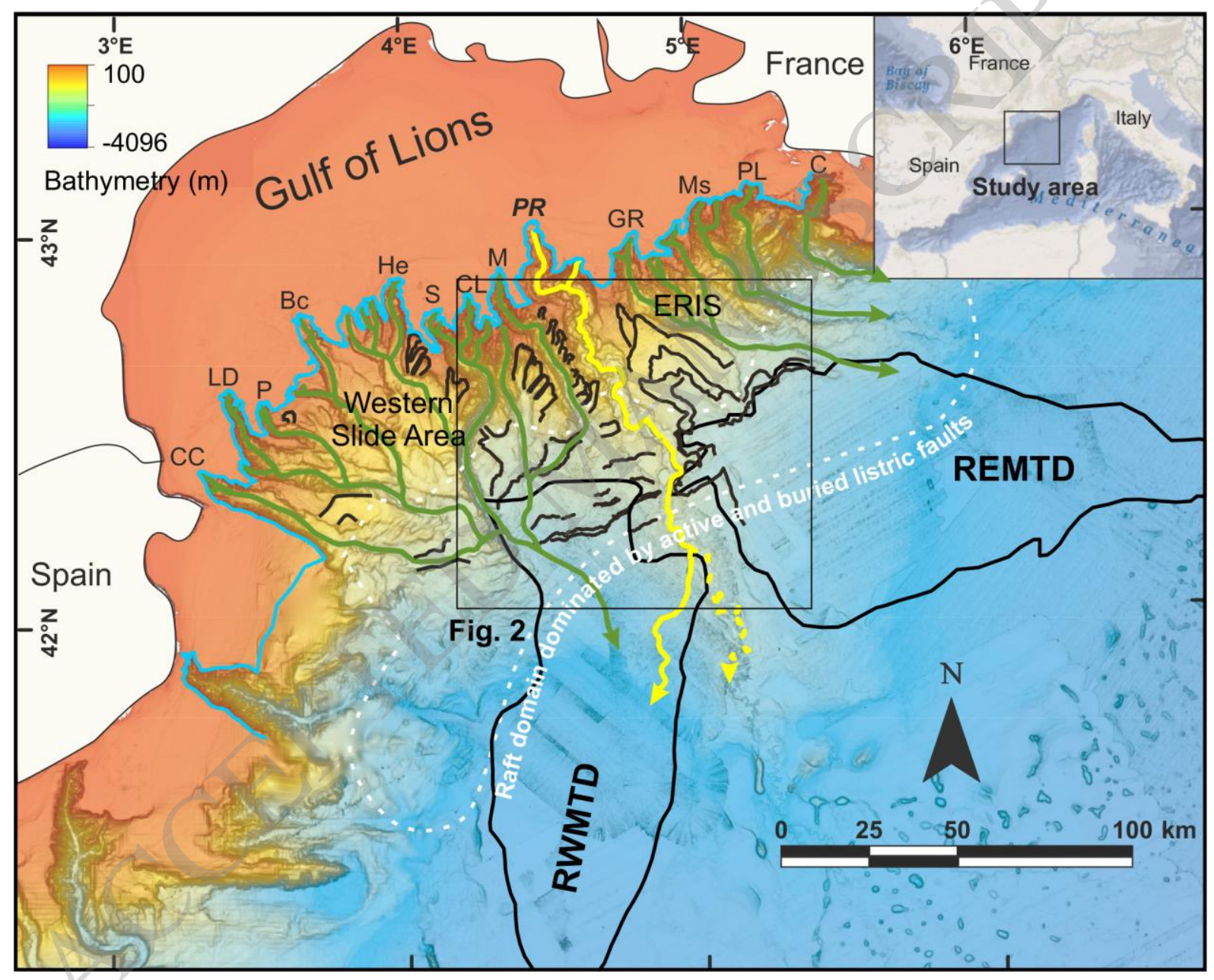




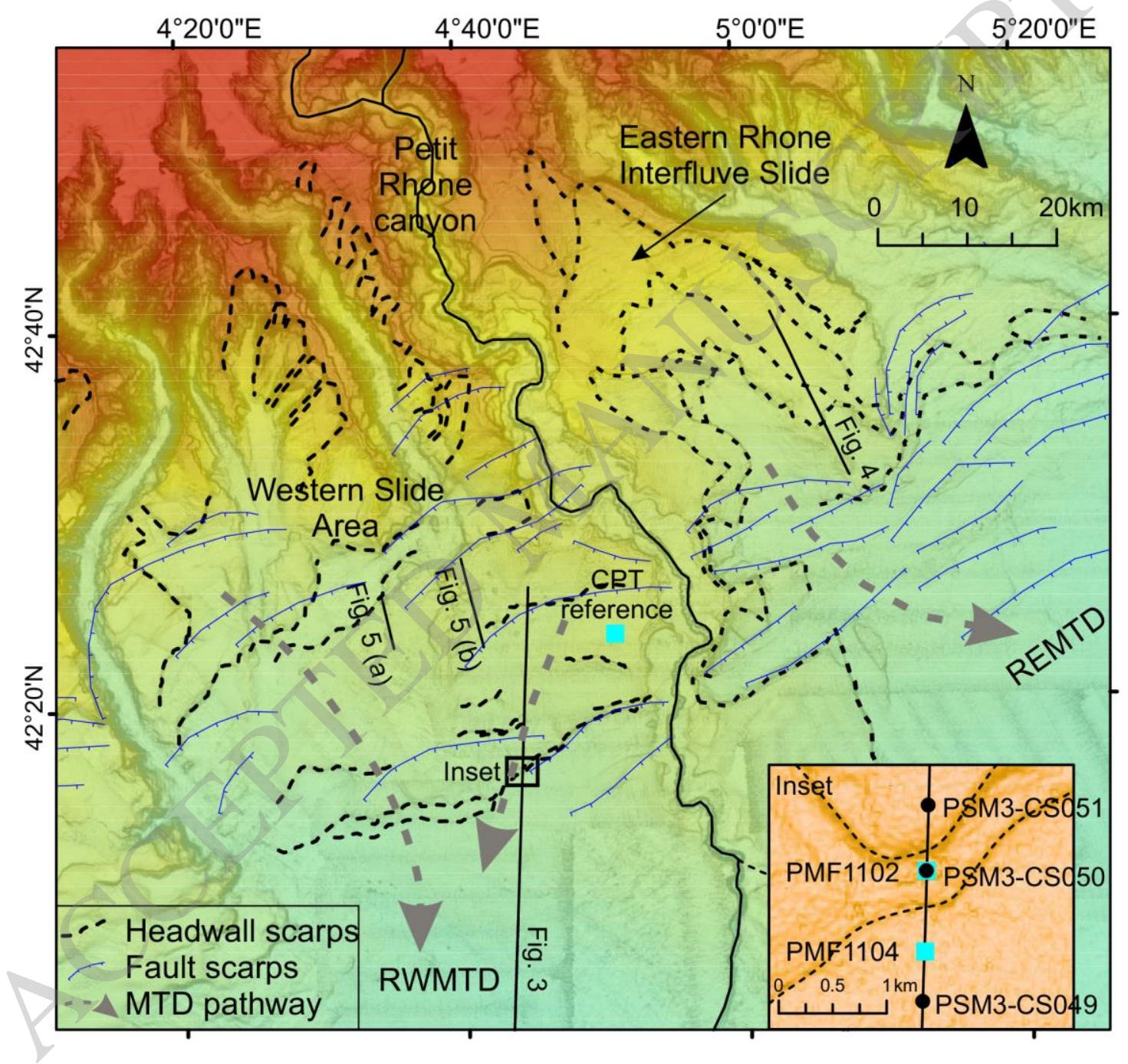




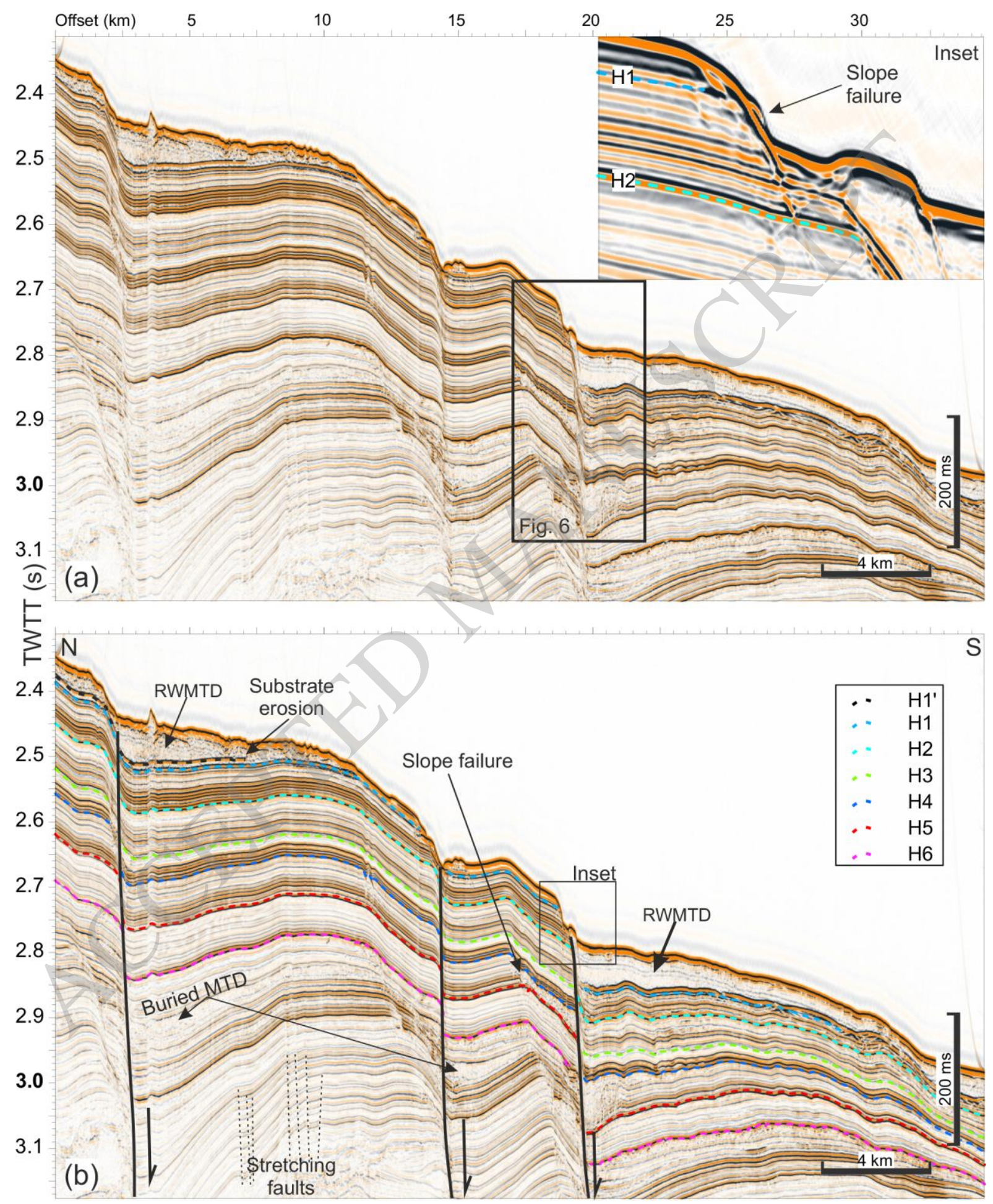




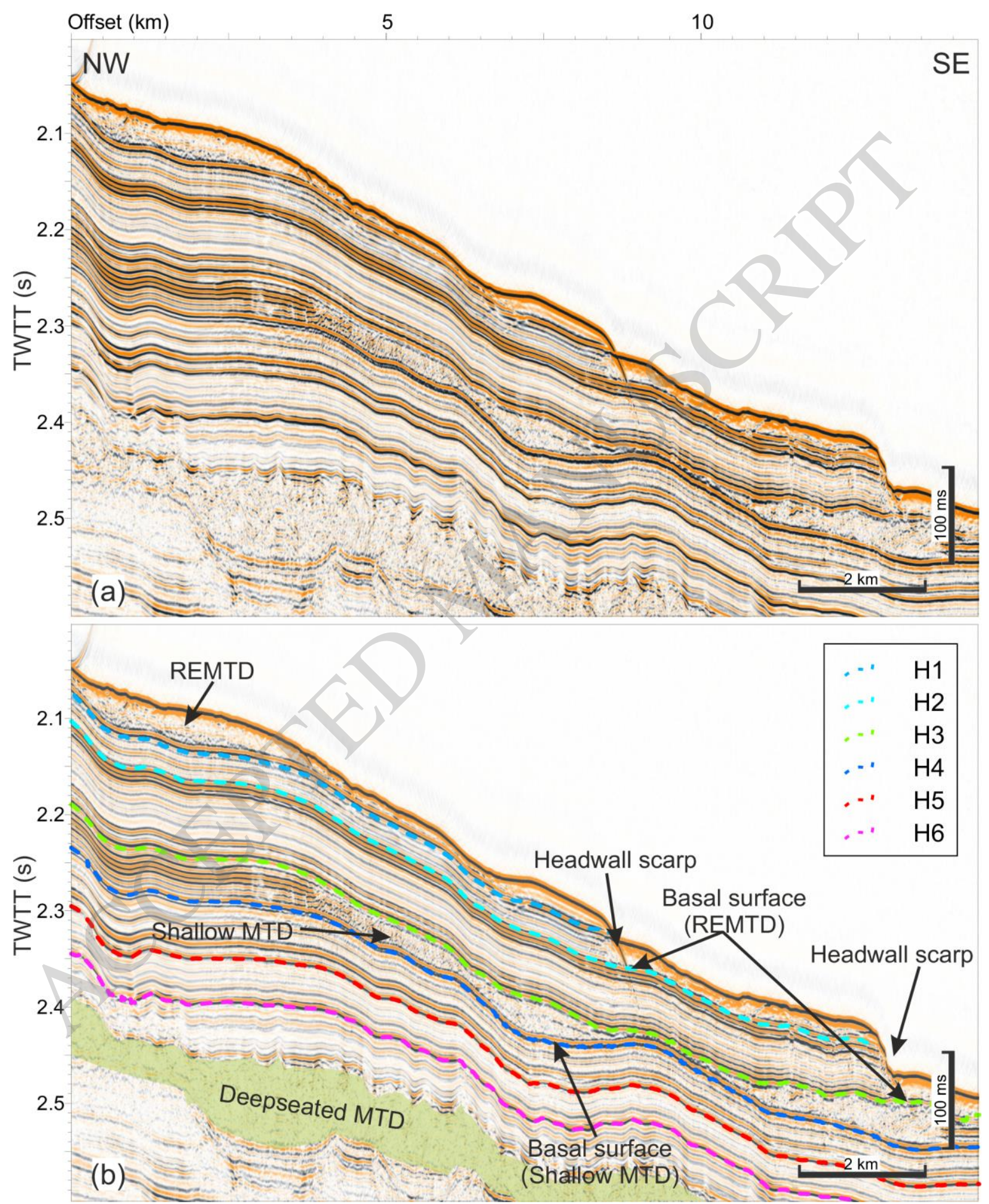




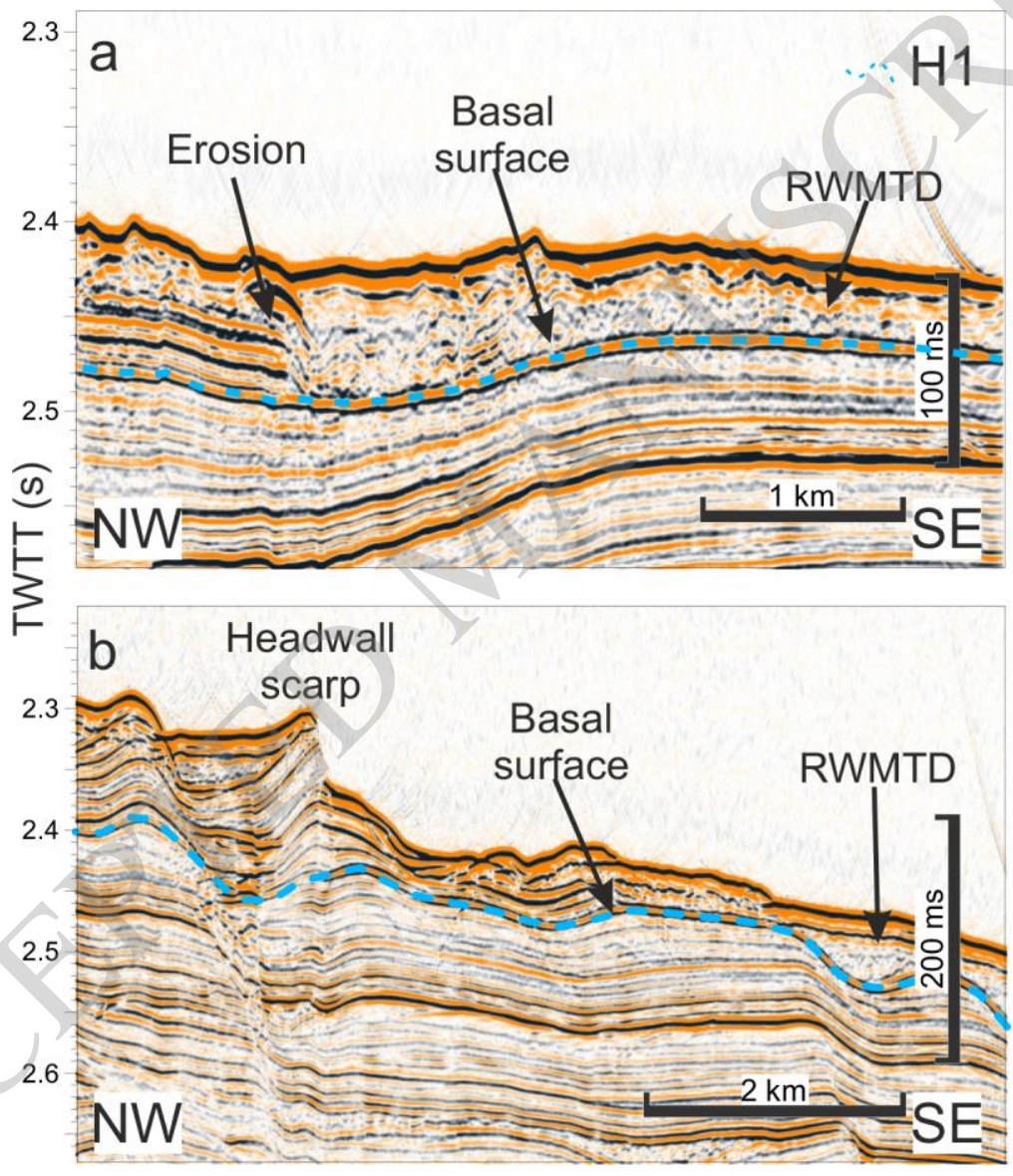




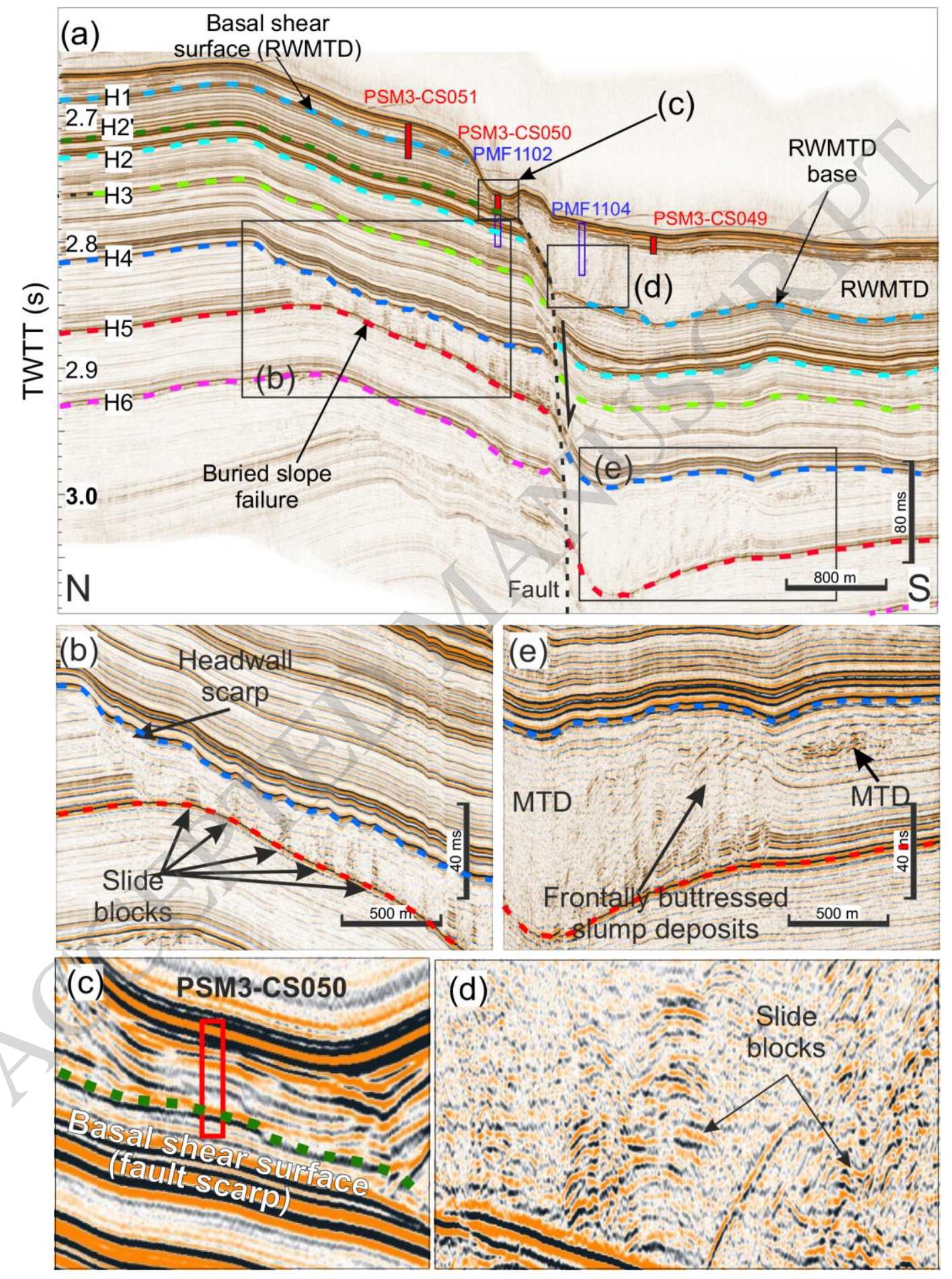


Downloaded from http://sp.lyellcollection.org/ by guest on February 28, 2020

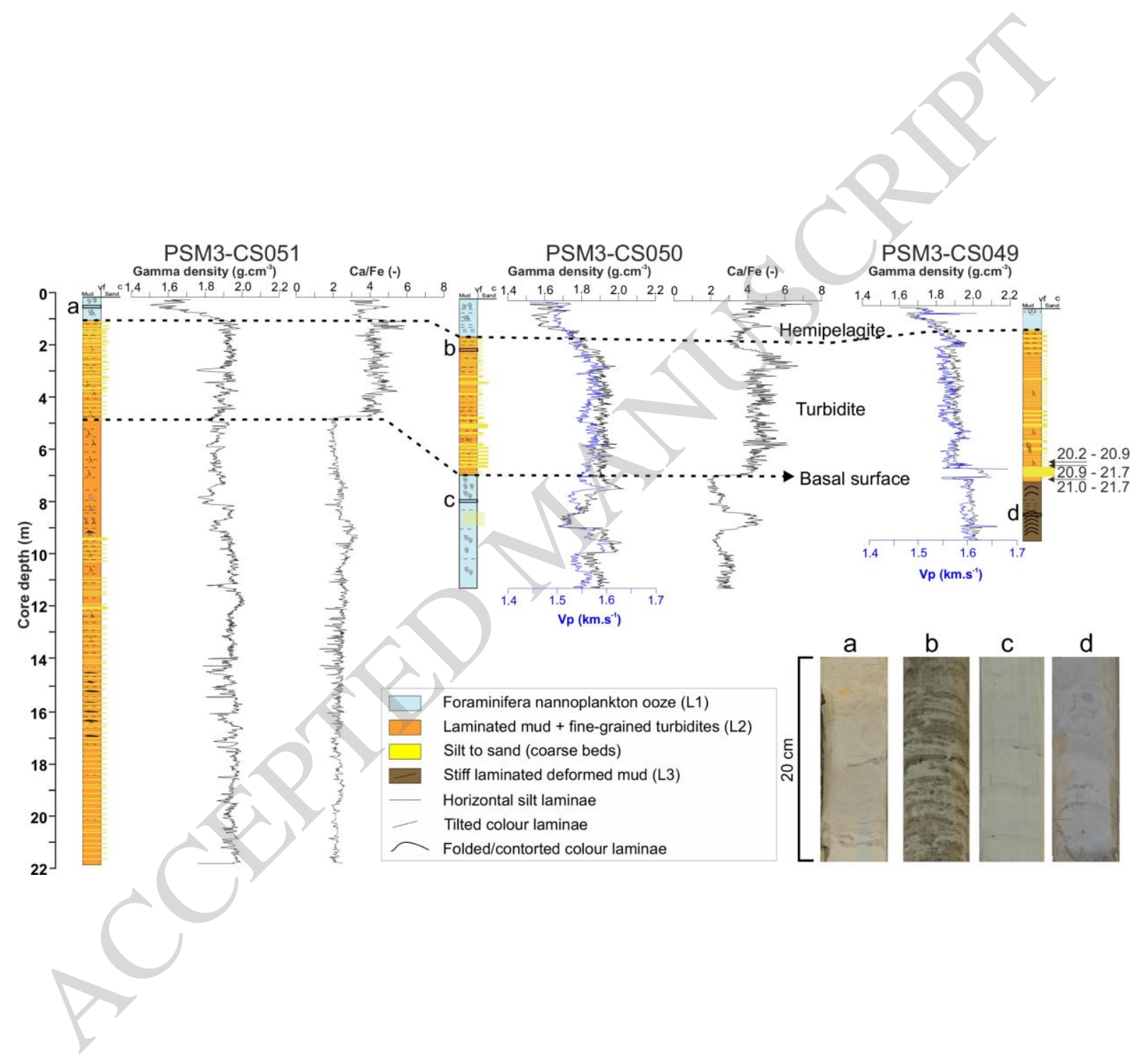




\section{Core PSM3-CS050}

(a)

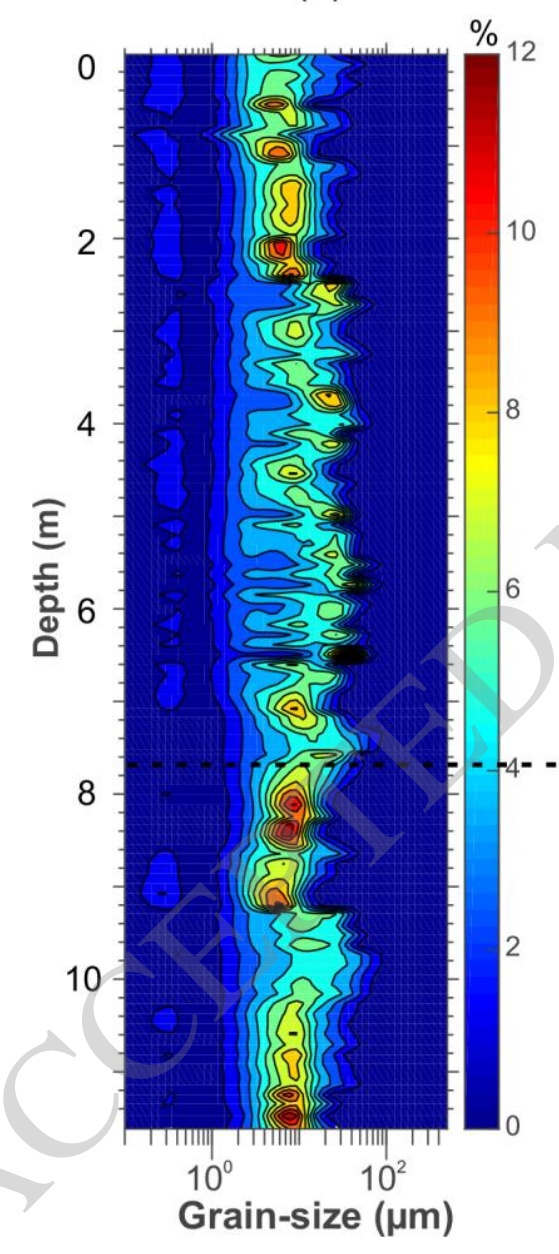

(b)

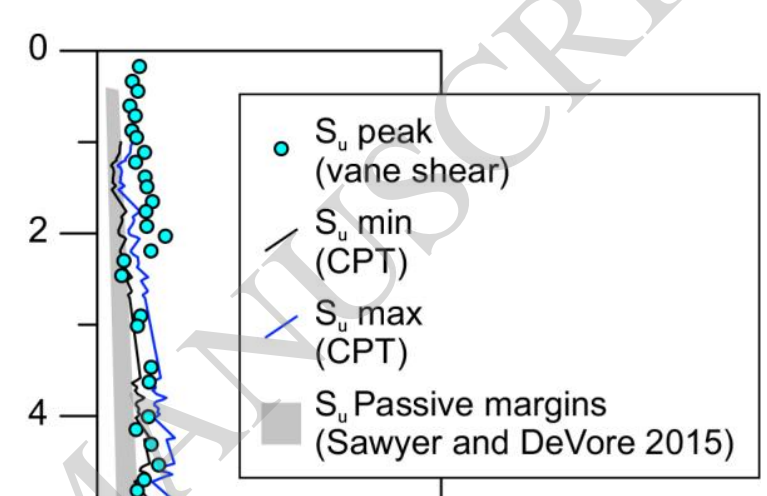


(a) CPT PFM-1101 Seismic $\quad \mathrm{q}_{\mathrm{t}}(\mathrm{MPa}) \quad \mathrm{f}_{\mathrm{s}}(\mathrm{kPa}) \quad \Delta \mathrm{u}_{2}(\mathrm{MPa}) \quad \mathrm{Su}(\mathrm{kPa}) \quad$ St $(-) \quad$ OCR $(-) \quad$ Soil type

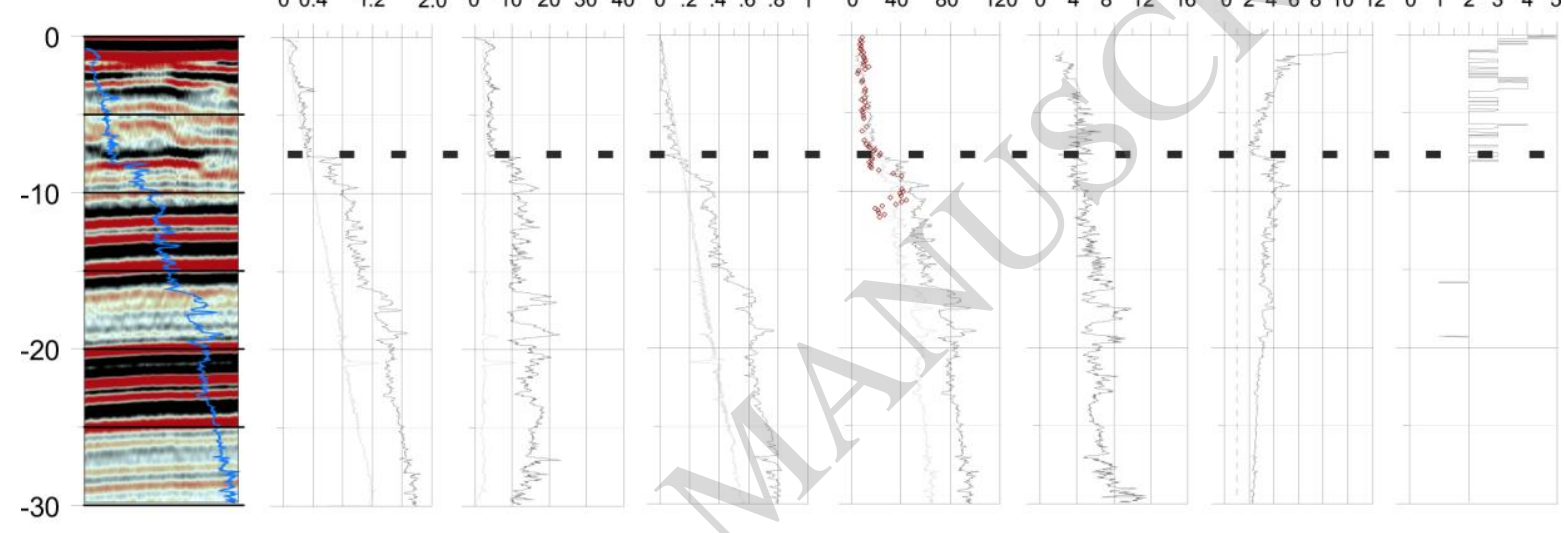

(b)

\section{CPT PFM-1104}

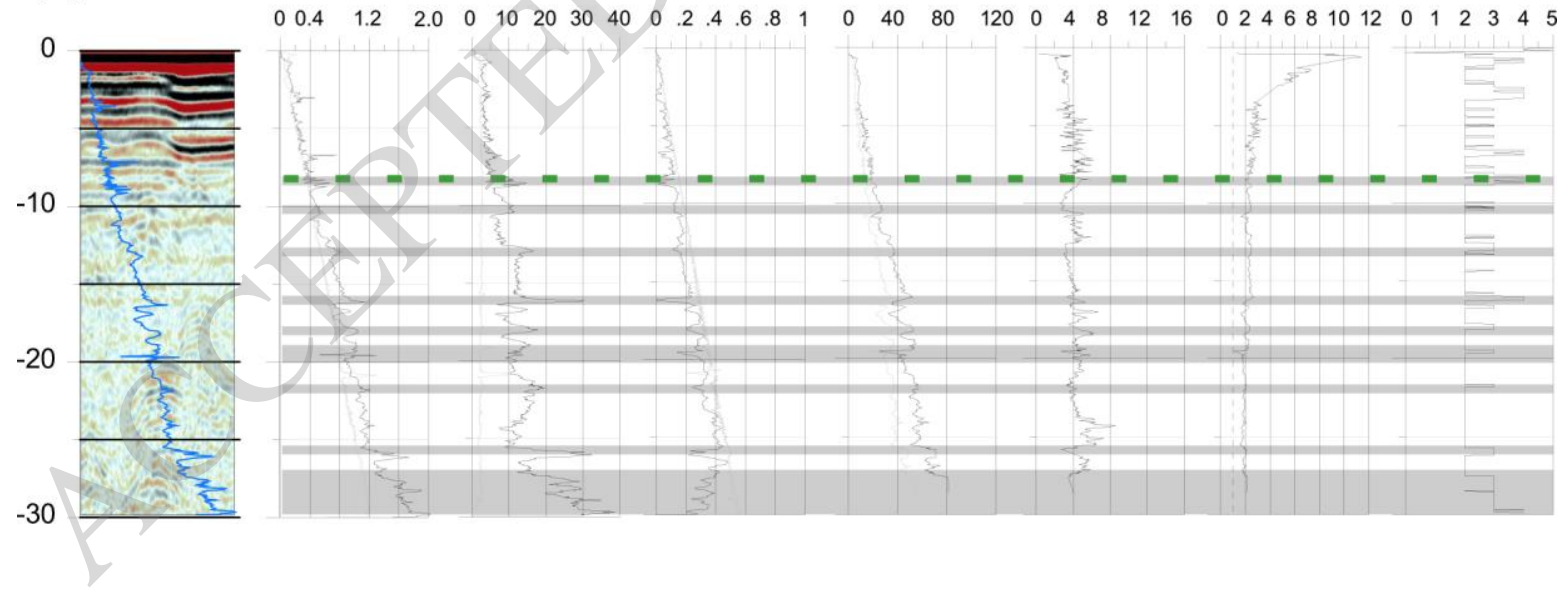

